\title{
The impact of the COVID-19 pandemic on health service utilisation following self- harm: a systematic review
}

Sarah Steeg*, Centre for Mental Health and Safety, Division of Psychology and Mental Health, University of Manchester; Manchester Academic Health Science Centre, Manchester, UK.

Ann John I, Medical School, Swansea University, Swansea, UK; Public Health Wales NHS Trust, Swansea, UK.

David Gunnell ף, Population Health Sciences; University of Bristol, Bristol, UK; National Institute for Health Research Biomedical Research Centre at the University Hospitals Bristol and Weston NHS Foundation Trust and the University of Bristol, Bristol, UK.

Nav Kapur, Division of Psychology and Mental Health, University of Manchester, Manchester, UK; NIHR Greater Manchester Patient Safety Translational Research Centre, Manchester, UK; Greater Manchester Mental Health NHS Foundation Trust, Manchester, UK.

Dana Dekel, Population Psychiatry, Suicide and Informatics, Swansea University, Swansea, UK.

Lena Schmidt, Sciome LLC, Research Triangle Park, North Carolina, 27713, USA; Bristol Medical School, University of Bristol, Bristol, UK.

Duleeka Knipe, Population Health Sciences; University of Bristol, Bristol, UK.

Ella Arensman, School of Public Health and National Suicide Research Foundation, University College Cork, Ireland and Australian Institute for Suicide Research and Prevention, School of Applied Psychology, Griffith University, Brisbane, Australia.

Keith Hawton, Centre for Suicide Research, University Department of Psychiatry, University of Oxford, UK; Oxford Health NHS Foundation Trust, Warneford Hospital, Oxford, UK.

Julian PT Higgins, National Institute for Health Research Applied Research Collaboration West (NIHR ARC West) at University Hospitals Bristol and Weston NHS Foundation Trust, Bristol, UK; Population Health Sciences, Bristol Medical School, University of Bristol, Bristol, 
medRxiv preprint doi: https://doi.org/10.1101/2022.01.26.22269901; this version posted January 28, 2022. The copyright holder for this preprint

(which was not certified by peer review) is the author/funder, who has granted medRxiv a license to display the preprint in perpetuity.

It is made available under a CC-BY-ND 4.0 International license .

UK; National Institute for Health Research Biomedical Research Centre at the University Hospitals Bristol and Weston NHS Foundation Trust and the University of Bristol, Bristol, UK

Emily Eyles, National Institute for Health Research Applied Research Collaboration West at University Hospitals Bristol and Weston NHS Foundation Trust, Bristol, UK; Population Health Sciences, Bristol Medical School, University of Bristol, Bristol, UK.

Catherine Macleod-Hall, Population Health Sciences, Bristol Medical School, University of Bristol, Bristol, UK.

Luke A McGuiness, Population Health Sciences, Bristol Medical School, University of Bristol, Bristol, UK.

Roger T Webb, Division of Psychology and Mental Health, University of Manchester, Manchester, UK; NIHR Greater Manchester Patient Safety Translational Research Centre, Manchester, UK.

*Corresponding author

I Contributed equally 


\section{Abstract}

Background

Evidence on the impacts of the pandemic on healthcare presentations for self-harm has accumulated rapidly. However, existing reviews do not include studies published beyond 2020.

Aims

To systematically review evidence on health services utilisation for self-harm during the COVID-19 pandemic.

Methods

A comprehensive search of multiple databases (WHO COVID-19 database; Medline; medRxiv; Scopus; PsyRxiv; SocArXiv; bioRxiv; COVID-19 Open Research Dataset, PubMed) was conducted. Studies reporting presentation frequencies for self-harm published from $1^{\text {st }}$ Jan. 2020 to $7^{\text {th }}$ Sept. 2021 were included. Study quality was assessed using a critical appraisal tool.

Results

Fifty-one studies were included. 59\% (30/51) were rated as 'low' quality, 29\% (15/51) as 'moderate' and 12\% (6/51) as 'high-moderate'. Most evidence (84\%, 43/51 studies) was from high-income countries. $47 \%(24 / 51)$ of studies reported reductions in presentation frequency, including all 6 rated as high-moderate quality, which reported reductions of $17-$ $56 \%$. Settings treating higher lethality self-harm were overrepresented among studies reporting increased demand. Two of the 3 higher quality studies including study observation months from 2021 reported reductions in service utilisation. Evidence from 2021 suggested increased use of health services following self-harm among adolescents, particularly girls.

\section{Conclusions}

Sustained reductions in service utilisation were seen into the first half of 2021. However, evidence from low- and middle-income countries is lacking. The increased use of health services among adolescents, particularly girls, into 2021 is of concern. Our findings may 
medRxiv preprint doi: https://doi.org/10.1101/2022.01.26.22269901; this version posted January 28, 2022. The copyright holder for this preprint (which was not certified by peer review) is the author/funder, who has granted medRxiv a license to display the preprint in perpetuity.

It is made available under a CC-BY-ND 4.0 International license .

reflect changes in thresholds for help seeking, use of alternative sources of support and variable effects of the pandemic across different groups. 


\section{Introduction}

The COVID-19 pandemic has led to deterioration in population mental health and has placed considerable additional strains on health systems. ${ }^{12}$ The pandemic has also heightened many of the risk factors for suicidal behaviour, such as job insecurity and unemployment, access to food, education and healthcare and the availability of family and community support. ${ }^{3}$ Understanding and quantifying trends in help seeking for self-harm is a vital part of the public mental health response to COVID-19. It could help expound the apparent paradox observed during the early stages of the pandemic; while population mental health deteriorated, ${ }^{4}$ fewer people sought help for their mental health from primary and secondary care services. ${ }^{5}$ Examining self-harm presentations across health settings could help understand longer-term population impacts and inform planning of services and interventions in the future phases of the pandemic.

Numerous studies from high-income countries reported marked reductions in health service utilisation during the second quarter of 2020 following the start of the COVID-19 pandemic. For example, considerable reductions in diagnoses for acute physical and mental illnesses were found in the UK following introduction of the national lockdown in March 2020, with only partial recovery by July 2020. ${ }^{6}$ In another UK study, reductions of around a third in health service contacts specifically for self-harm were found. ${ }^{7}$ Focussing specifically on hospital admission for self-harm, overall reductions of just over $8 \%$ were reported in France, though increases in more serious potentially lethal acts of self-harm were observed. ${ }^{8}$ Evidence relating to the indirect health impacts resulting from the pandemic in low- and middle-income countries also suggests care for non-communicable diseases and mental disorders has been severely disrupted. ${ }^{9}$ A systematic review on the impact of the pandemic on suicide and self-harm in low- and middle-income countries found mixed evidence, with either a decrease or no discernible impact in reported self-harm episodes along with increases in certain age groups. ${ }^{10}$

In 2020, a living systematic review was established to provide an up-to-date resource and data synthesis of evidence on the impact of the COVID-19 pandemic on self-harm and suicidal behaviour. ${ }^{11}$ The most recent update of the review included studies up to $19^{\text {th }}$ October 2020 and included 20 health service utilisation studies, including 11 focussing specifically on health service contact following self-harm/suicide attempts. ${ }^{12}$ The review reported that most studies reported a decrease in presentations to health services for selfharm during the early months of the COVID-19 pandemic. 
However, all 20 studies were of high-income countries and the latest month of observation was August 2020. ${ }^{13-15}$ In the subsequent months many health services adapted and 'stay at home' orders eased, although these restrictions later returned in many countries and regions. While studies suggest service utilisation had returned to expected volumes in some countries by the third quarter of $2020,{ }^{12}$ it is not known how subsequent restrictions and ongoing pressures on health systems in response to further waves of COVID-19 affected help-seeking and access to healthcare for self-harm. In this article we report on evidence concerning the frequency (reported incident or prevalent episode counts or rates) of health service utilisation for self-harm after the onset of the pandemic compared to before the pandemic. There has been no synthesis of studies published since October 2020, some of which would be expected to include the later observation periods covering the latter months of 2020 and first half of 2021, as the pandemic continued to affect populations globally. Our aim was to systematically identify, review and synthesise evidence relating to utilisation of health services for self-harm since the COVID-19 pandemic began in the first quarter of 2020.

\section{Methods}

The protocol for the methodology applied in conducting the systematic review is registered within a living systematic review of the impact of the COVID-19 pandemic on self-harm and suicidal behaviour (PROSPERO ID CRD42020183326; registered on 1st May 2020). ${ }^{11512}$ Additional inclusion and exclusion criteria specific to our research question were applied and further screening, data extraction and study quality assessments were conducted. To address our research question, 'did the frequency of health service presentation for selfharm during the pandemic change compared to antecedent periods?', we applied the following inclusion and exclusion criteria:

\section{Inclusion criteria}

- Published from $1^{\text {st }}$ Jan. 2020 to $7^{\text {th }}$ Sept. 2021.

- Written in any language.

- Investigation of health service utilisation among the general population

- Including presentations to general hospital emergency departments (EDs), primary healthcare services, specialist mental healthcare services (accessible to general population), other secondary healthcare services that treat people who have self-harmed / attempted suicide (e.g. surgery) and admission to hospitals. 
- Outcomes were presentations for self-harm, including:

○ broad definition of self-harm (defined as non-fatal intentional self-injury, intentional self-poisoning involving drugs or non-ingestible substances, including non-suicidal acts) or attempted suicide, including hospital attendance and/or admission for these reasons ${ }^{11}$

- narrower definition, for example studies focussed only on suicide attempts or specific methods of self-harm.

- Comparisons:

○ health service presentation frequencies (including incident or prevalent episode counts or rates) for self-harm before and after the beginning of the COVID-19 pandemic, considering specific time periods separately; for example, both initial and subsequent lockdown periods.

\section{Exclusion criteria}

- Studies without pre-pandemic observation periods or measurements, including those reporting use of service initiatives implemented in response to the pandemic, with no pre-pandemic comparison period.

- Reports where only an abstract was available.

- Studies focussing on specific groups such as those with a specific physical of psychiatric diagnosis (including COVID-19) or where the baseline population was existing patients within a specialist service, such as psychiatric inpatients.

- Studies reporting self-harm and suicidal thoughts as a combined measure.

- Studies reporting proportions of self-harm presentations, without reporting absolute figures

- Studies of suicides.

\section{Data analysis}

The list of studies used for screening was obtained from the main living systematic review database. ${ }^{12}$ This database is updated automatically using daily electronic searches of multiple databases (WHO COVID-19 database; Medline; medRxiv; Scopus; PsyRxiv; SocArXiv; bioRxiv; COVID-19 Open Research Dataset, PubMed) (see Supplement 2 for search strategy for each database). Screening was conducted in two stages: the citations returned by the automated searches were assessed by four screeners $(C O, E E, D D, C M-H)$ to identify potentially relevant studies, then AJ, DG, DK or RW assessed the full text of the 
medRxiv preprint doi: https://doi.org/10.1101/2022.01.26.22269901; this version posted January 28, 2022. The copyright holder for this preprint

studies to identify studies to be included in the main living systematic review. In addition, expert reviewers (AJ, DG, DK and RW) completed daily assessments of the automated results, which included basic data extraction and assigning studies manually to a study design category, along with a description of the study design.

Identification and screening of studies for the current review was conducted using a methodology developed as part of an existing living systematic review (Fig. 1). ${ }^{12}$ Studies included publications identified in the living systematic review from $1^{\text {st }}$ Jan. 2020 up to $7^{\text {th }}$ Sept. 2021. Screening was conducted according to the inclusion and exclusion criteria for the current review. The list of studies was extracted from the main living systematic review database on $14^{\text {th }}$ Sept. 2021. Categories assessed for inclusion in the current review were 'service utilisation', 'before/after studies', 'time trends analysis' and 'examination of electronic health records' (Fig. 1). ${ }^{16}$

As part of the identification and screening procedure, further screening and data extraction was completed for the current systematic review using a proforma designed to collect standardised information from each study (Table S1). Study quality and risks of bias were assessed using an adapted version of an existing National Institute for Health (NIH) quality assessment tool, designed specifically for studies using before and after designs. ${ }^{17} \mathrm{The} \mathrm{NIH}$ tool was adapted by authors DK, JH and DG to include consideration of the pandemic and associated lockdown periods and other societal restrictions as the intervention of interest and to account for the use of health service data sources in the study designs. The overall assessment tool was used to judge the quality of studies, with predefined criteria established for studies to be rated as high or moderate quality. Screening, data extraction and quality assessments were conducted by SS. A second rater (DD) assessed eligibility for $20 \%$ of the studies sought for retrieval and conducted independent data extraction and analysis on $10 \%$ of the included studies. There was agreement on all eligibility assessments and study quality ratings. If a source was not available in English, data extraction was conducted by expert reviewers fluent in the language that the article was written in. Where included studies were preprints, searches for peer-reviewed version were conducted and the updated peerreviewed version was used for data extraction where available. Data synthesis was conducted by extracting, assessing and tabulating key aspects of the studies, including setting, study design, data sources, outcome measures, follow-up and comparison periods, main findings and study quality. The main effect measure of interest was percentage difference in presentation frequency during a defined COVID-19 period compared to a preCOVID-19 comparison period. If this data were missing, the overall direction of change (e.g. 
increase/no change/decrease) was recorded. Higher quality studies were prioritised and reported separately during data synthesis and presentation of results.

\section{Results}

Description of included studies

Fifty-one studies were included. These were from healthcare settings including general hospital EDs (39\%, 20/51), trauma and surgery admissions (22\%, 11/51), children's hospitals $(8 \%, 4 / 51)$, primary care $(8 \%, 4 / 51)$, general hospital admissions $(6 \%, 3 / 51)$, paediatric EDs $(6 \%, 3 / 51)$, ambulance calls $(4 \%, 2 / 51)$, liaison psychiatry referrals $(4 \%$, $2 / 51)$ paediatric trauma admissions $(2 \%, 1 / 51)$ and a multiservice setting $(2 \%, 1 / 51)$ (Table 1 and Table S1). Study quality was mixed; $59 \%$ (30/51) were rated as 'low' quality, $29 \%$ (15/51) as 'moderate' and $12 \%(6 / 51)$ as 'high-moderate'. Reasons for studies being rated as low quality commonly included small event counts, absence of clearly defined patient eligibility criteria, and poorly described data extraction/collection methodology. Most of the evidence (84\%, 43/51 studies) was from investigations conducted in high-income countries (Table 1). Forty-two of the 51 studies were reported in peer-reviewed articles, four were preprints, four were letters or editorials and one was a report.

\section{Findings of included studies}

Almost half $(47 \%, 24 / 51)$ of the studies reported reductions in presentation frequency (Figure 2) for the duration of the period studied, the majority of which included months no later than August 2020. All 6 studies rated as high-moderate quality found decreases in service utilisation during the early months of the pandemic, with reductions of between 17 and $56 \%$ reported. ${ }^{6718-21}$ These studies were of primary and secondary care settings combined (4 studies), ED presentations among ages 18 to 25 years (1 study) and selfpoisoning presentations to hospital (1 study). Four studies used healthcare records in the UK to compare expected vs. observed primary and secondary-care recorded episodes of self-harm, and found reductions of between 26 and 44\%. 671921 Another study based in Sri Lanka found a $32 \%$ reduction in hospital presentations for self-poisoning compared to prepandemic numbers. However, these estimates included months no later than August 2020.

Five studies used national or nationally representative data. Four of these were assessed as high-moderate quality and reported decreases in service utilisation of between 26 and 56\%. One moderate quality study reported a $6 \%$ increase in ED presentations. ${ }^{22}$ This US-based 
study only included self-harm episodes classified as suicide attempts, therefore may not reflect service use for self-harm more broadly.

Increases were reported in 15/51 (29\%) studies, none of which were assessed as being of high-moderate quality and 4 were rated as moderate quality. An examination of the number of people admitted to a surgical department following self-harm by ingestion of corrosive substances was found to increase by $55 \%$ in one Bangkok hospital, though numbers in the study were relatively low. ${ }^{23}$ Other moderate quality studies reporting increased patient numbers included ED and surgery services, settings likely to be encountering patients with more medically severe episodes of self-harm.

Twelve out of 51 (24\%) studies reported no change in service utilisation, including no highmoderate quality studies and 2 assessed as moderate quality. These were both conducted in ED settings, with one New Zealand ED reporting no change in self-harm presentations ${ }^{24}$ and a UK-based study reporting no change in hospital admission following ED presentations for self-harm ${ }^{25} \mathrm{~A}$ further 6 studies were conducted in trauma settings, though all were rated as low quality.

Most studies (46/51) included up to a maximum of 8 months of follow-up from the first wave of the pandemic (March to October 2020). Among the 4 studies including months from 2021 in their observation period (up to May 2021), 3 were rated as high-moderate quality. Among these, 2 studies of primary and secondary care-recorded self-harm reported longer-term reductions of between 8 and $30 \%$ respectively ${ }^{1921}$ and another study of ED presentations by young people aged 12 to 25 years found no overall change. ${ }^{18}$ Studies including follow-up months beyond 2020 were limited to those originating from high-income countries.

\section{Findings by study settings and subgroups}

$7 / 51$ (14\%) studies were conducted in upper-middle-income (3 studies), middle-income (1) and lower-middle income (3) countries, one of which was rated as high-moderate quality. Four studies found a decrease in service use and three reported an increase. The study rated as high-moderate quality reported on self-poisoning episodes in a lower-middleincome setting; using health record data from a toxicology unit in a Sri Lankan hospital, a $32 \%$ reduction in hospital presentations for self-poisoning was found compared to prepandemic numbers. ${ }^{20} \mathrm{~A}$ study of moderate quality conducted in one Nepalese ED found an increase of $44 \%$ in presentations for self-harm during the lockdown period compared to the same period the previous year, with indications that severity of self-harm was higher, though 
the numbers of presentations in both the lockdown and comparison periods were relatively small. ${ }^{26}$

Eighteen studies included examination of service use for self-harm specifically among children and/or young people, with five rated as high-moderate quality. One high-moderate quality study including approximately $71 \%$ of the US's EDs in 49 states examined presentations among ages 18 to 25 years and found reductions of $26 \%$ among ages $12-17$ and $17 \%$ among ages 18-25 in April 2020. However, when examining presentation rates over the longer-term, through to March 2021, increases compared to equivalent weeks in 2019 were found for girls aged 12-17. Among boys aged 12-17 and all adults aged 18-25 years, rates through to March 2021 were in line with those in $2019 .{ }^{18}$ Another highmoderate quality study, based in the UK, reported increased numbers of presentations to primary and secondary care among all adolescents aged 10-17 years up to May 2021. ${ }^{19}$ These findings are in contrast to those reported in other moderate quality studies using earlier COVID-19 observation periods (up to June 2020) where younger people were found to have significantly fewer self-harm presentations than in the equivalent period in $2019 .{ }^{2728}$

\section{Discussion}

\section{Main findings}

All of the studies assessed as high-moderate quality reported decreases in service utilisation following self-harm and were conducted in settings reflecting a broad spectrum of self-harm with higher frequency of presentations such as primary care. We found that settings treating episodes of self-harm with lower frequency and higher lethality, such as trauma admissions and ambulance calls, were overrepresented among studies that reported increased or no change in demand. Among higher quality studies that included months from 2021 in their observation period, numbers of people seeking help from health services were found to be either closer to pre-pandemic levels, though still lower than expected, or in line with expected numbers. Evidence from 2021 also suggested there was increased utilisation of health services following self-harm among adolescents, girls particularly so. However, studies including follow-up months from 2021 were limited to those originating from highincome countries.

\section{Strengths and limitations}


This systematic review is the first to examine up-to-date evidence regarding associations between the COVID-19 pandemic and frequency of health service utilisation for self-harm. An established, peer-reviewed living systematic review methodology, ${ }^{11}$ with ongoing data extraction by a panel of suicide prevention experts, was used as the basis for this review. This approach, along with a specific focus on studies comparing frequency in utilisation of health services following self-harm in different settings during the COVID-19 pandemic versus antecedent pre-pandemic periods, enables timely synthesis of the evolving evidence base.

The findings of our study should be interpreted with some important caveats in mind. We excluded 6 studies that reported self-harm and suicidal thoughts as a combined measure as it was not possible to make a like-for-like comparison with findings pertaining specifically to acts of self-harm. However, we included studies using a broad range of definitions of selfharm, including those that measured and reported on suicide attempts or self-poisoning methods only. We also did not include temporal trends in the proportion of all presentations that were for self-harm as a primary outcome, due to the limitation that this outcome would be affected by changes in the overall number of presentations for reasons other than selfharm.

We conducted a comprehensive narrative synthesis of the data rather than a meta-analysis due to heterogeneity in the pandemic and antecedent comparison periods, definitions of selfharm applied, and healthcare settings that studies were conducted in. Performing a metaanalysis will be considered for future updates of the living systematic review. The studies included in our review are of mixed quality and are greatly under-representative of middleand low-income countries. While we have reported findings according to these characteristics, overall findings should be interpreted in light of these considerations.

\section{Implications and comparison with existing evidence}

Most studies came from high-income countries. Findings from higher quality studies suggested either there were continued reductions in health service utilisation into 2021, though to a lesser extent than earlier months of the pandemic, or that service use had broadly returned to pre-pandemic levels. However, these findings cannot necessarily be generalised to low- and middle-income countries. For example, allocation of COVID-19 vaccinations has been disproportionately skewed towards high-income countries. ${ }^{29}$ Consequently, many low- and middle-income countries have experienced major subsequent waves of COVID-19 well into $2021 .{ }^{30}$ The effects of these further waves of infection on 
medRxiv preprint doi: https://doi.org/10.1101/2022.01.26.22269901; this version posted January 28, 2022. The copyright holder for this preprint

many of the factors associated with self-harm - for example, unemployment, mental and physical ill health, poor access to healthcare - are likely to be considerable. ${ }^{31}$ Subsequent waves of COVID-19 have also been experienced by high-income countries into the latter half of 2021. For example, from November 2021, some European countries introduced further societal restrictions. ${ }^{32}$ Continued surveillance is therefore needed in all settings.

Our findings are consistent with reports of increased acuity of presentations in some mental health services. ${ }^{33} 34$ The increases in presentation frequency reported by studies that were conducted in healthcare settings treating more potentially lethal episodes of self-harm, such as ambulance calls and trauma admissions indicates that the pandemic has impacted the threshold for help seeking. Evidence also shows that non-statutory mental health services, such as charities, experienced increased demand in the months following the onset of the pandemic. ${ }^{35}$ This may explain the apparent paradox observed during the first year of the pandemic, where deterioration in population mental health alongside reductions in health services utilisation was observed. This indicates that reductions seen in settings capturing a broader spectrum of self-harm do not simply reflect decreased incidence of self-harm or reduced clinical need. People who have harmed themselves non-fatally have a markedly elevated suicide risk subsequently, irrespective of self-harm method at the index episode, and degrees of suicidal intent can fluctuate between different self-harm episodes by the same person. ${ }^{36}$ Therefore, it is vital that people harming themselves receive clinical intervention and that health services across the world work to ensure services are available to provide timely and accessible care. ${ }^{37} 38$

Studies examining changes in proportions of groups presenting with certain characteristics, and those examining combined 'suicidal thoughts and self-harm' outcomes, were not included in this systematic review as we were interested in absolute numbers of people using health services for self-harm. However, such studies can provide valuable information about help seeking behaviour in different groups. For example, a study of hospital attendance for suicidal ideation and self-harm in Australia's Gold Coast region identified a number of groups with particularly reduced likelihood of presentation during March to August 2020, including Indigenous Australians and individuals with less severe suicidal and selfharm, while people younger than 18 years had increased numbers of presentations. ${ }^{39}$ Another study conducted in a paediatric ED in New York City, USA found that while overall there were significant decreases in emergency attendances, visits for suicidal ideation and self-harm among young people increased. ${ }^{40}$ Increases in numbers of adolescents referred to mental health services in Ireland were found from September 2020, following initial decline in April 2020. ${ }^{41}$ Our findings of increased utilisation of health services for self-harm 
into the early months of 2021 among adolescents, particularly girls, within this context, are concerning and warrant urgent attention.

\section{Conclusions}

All high-quality studies reported a fall in attendance frequency for self-harm during the early months of the pandemic. New evidence relating to the first and second quarters of 2021 indicated that longer-term impacts on health services were less marked than during the first wave of the pandemic, though reductions in frequency of presentation versus expected levels persisted. These patterns likely reflect changes in thresholds for help seeking, increases in frequency of higher acuity episodes of self-harm and increased use of nonstatutory health services. The increased utilisation of health services among adolescents, particularly girls, into the early months of 2021 warrants particular attention. However, evidence from low- and middle-income countries is still limited. High-quality, multi-centre studies examining the longer-term impacts on health service utilisation for self-harm, particularly in low- and middle-income countries, including observation periods into 2021 and among children and young people, are urgently needed.

\section{Declaration of Interest}

DG, KH and NK are members of the Department of Health and Social Care (England)

National Suicide Prevention Strategy Advisory Group.

\section{Funding}

SS is funded by a University of Manchester Presidential Fellowship. NK and RTW are funded by the National Institute for Health Research (NIHR) Greater Manchester Patient Safety Translational Research centre.

\section{Acknowledgements}

The authors thank Dr Claire Huish, Dr Florian Walter and Dr Laszlo Trefan for conducting data extraction for non-English language studies.

\section{Author contributions}

Conceptualisation and design of study: SS, AJ, DG, RTW

Initial screening: EE, DD, CMH, DK, AJ, RTW, DG

Expert reviewing: AJ, DG, DK, RTW

Quality assessments: SS, DD 
medRxiv preprint doi: https://doi.org/10.1101/2022.01.26.22269901; this version posted January 28, 2022. The copyright holder for this preprint (which was not certified by peer review) is the author/funder, who has granted medRxiv a license to display the preprint in perpetuity.

It is made available under a CC-BY-ND 4.0 International license.

Data analysis: SS, DD, LS

Writing manuscript: SS

Critical reviewing and editing of manuscript: all authors 
medRxiv preprint doi: https://doi.org/10.1101/2022.01.26.22269901; this version posted January 28, 2022. The copyright holder for this preprint (which was not certified by peer review) is the author/funder, who has granted medRxiv a license to display the preprint in perpetuity.

It is made available under a CC-BY-ND 4.0 International license .

Figure 1: PRISMA flow diagram ${ }^{12}$

Identification of studies via databases

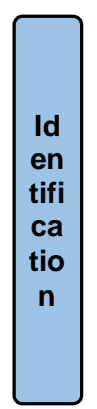

\begin{tabular}{|l|}
\hline \\
Sc \\
en \\
in \\
g \\
\end{tabular}

Reports sought for retrieval and assessed for eligibility

$(n=144)$

Records identified from living systematic review database from $1^{\text {st }}$ Jan. 2020 to $7^{\text {th }}$ Sep. 2021: Databases $(n=17,794)$ : WHO COVID-19 database; Medline (via PubMed); medRxiv; Scopus; PsyRxiv; SocArXiv; bioRxiv; CORD-19

Including all records categorised as:

- Service utilisation

- Before/after studies

- Time trends analysis

- Examination of electronic health records

Total studies included in review $(n=51)$
Records removed before screening: Reports categorised by living systematic reviewers as: Literature reviews

Analysis of media reports Studies of social media use Modelling studies

Qualitative studies Cross-sectional surveys

Reports excluded $(n=93)$ Outcome was suicide death $=35$ Outcome measured self-harm as a proportion of all presentations $=13$ Self-harm was combined with another outcome $=14$

Focussed on patients with a specific diagnosis $=7$

Suicidal ideation and plans only $=11$ No pre-COVID-19 comparison period $=5$ Duplicate $=3$

Self-report outcome measure $=1$

Article not located $=3$

Only abstract available $=1$ 
Figure 2: Percentage change in health service utilisation ordered by country income level and latest month of study observation period, grouped by study quality.

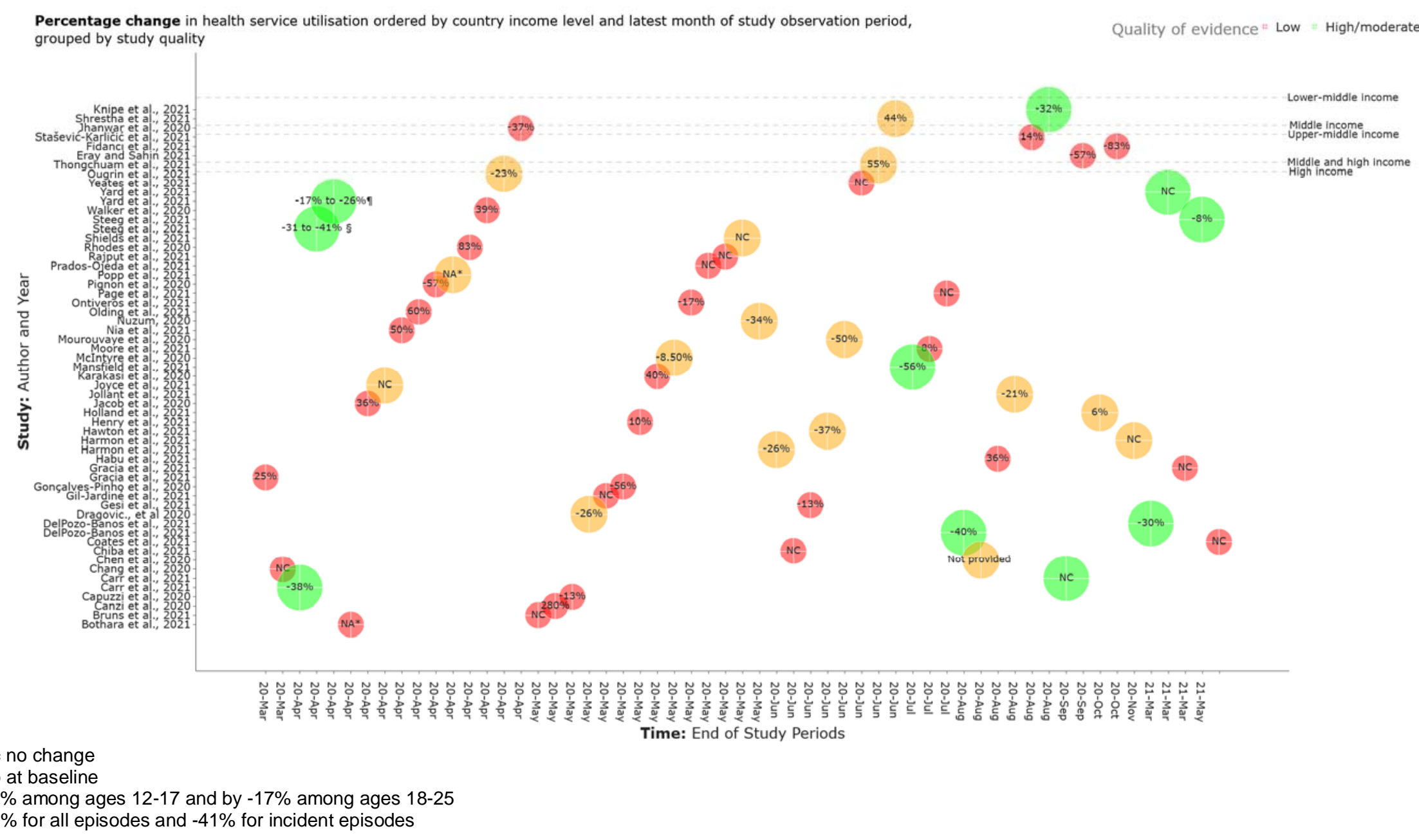


Table 1: Characteristics of included studies: $1^{\text {st }}$ Jan. 2020 to $7^{\text {th }}$ Sep. 2021

\begin{tabular}{|c|c|c|c|c|c|c|c|c|c|c|}
\hline $\begin{array}{l}\text { Stud } \\
\text { y ID }\end{array}$ & Authors & $\begin{array}{l}\text { Healthcare } \\
\text { setting }\end{array}$ & $\begin{array}{l}\text { Increase, } \\
\text { decrease or } \\
\text { no change }\end{array}$ & $\begin{array}{l}\text { Statistically } \\
\text { significant } \\
\text { change? }\end{array}$ & $\begin{array}{l}\text { Approx. \% } \\
\text { change } \\
\text { ( } 95 \% \mathrm{Cl} \text { if } \\
\text { provided) }\end{array}$ & $\begin{array}{l}\text { Latest } \\
\text { month of } \\
\text { study } \\
\text { period }\end{array}$ & $\begin{array}{l}\text { Change } \\
\text { post- } \\
\text { lockdown } \\
\text { (if studied) }\end{array}$ & $\begin{array}{l}\text { Additional, } \\
\text { post-Sep. } \\
2020 \text { period } \\
\text { examined }\end{array}$ & $\begin{array}{l}\text { Quality of } \\
\text { evidence }\end{array}$ & $\begin{array}{l}\text { Global } \\
\text { setting }\end{array}$ \\
\hline 1 & $\begin{array}{l}\text { Capuzzi et al., } \\
2020^{42}\end{array}$ & $\begin{array}{l}\text { ED } \\
\text { (psychiatric) }\end{array}$ & Decrease & Not reported & $-13 \%$ & May-20 & & & Low & High income \\
\hline 2 & $\begin{array}{l}\text { Carr et al., } \\
2021^{7}\end{array}$ & $\begin{array}{l}\text { Primary and } \\
\text { secondary }\end{array}$ & Decrease & Yes & $\begin{array}{l}-38 \%(\mathrm{Cl} \\
35 \% \text { to } 50 \%)\end{array}$ & Apr-20 & No change & Sep-20 & $\begin{array}{l}\text { High/modera } \\
\text { te }\end{array}$ & High income \\
\hline 3 & $\begin{array}{l}\text { Chen et al., } \\
2020^{43}\end{array}$ & $\begin{array}{l}\text { Liaison } \\
\text { psychiatry } \\
\text { referrals }\end{array}$ & Decrease & Yes & not provided & Aug-20 & & & Moderate & High income \\
\hline 4 & $\begin{array}{l}\text { Dragovic., et al } \\
202044\end{array}$ & ED & Decrease & Yes & $-26 \%$ & May-20 & & & Moderate & High income \\
\hline 5 & $\begin{array}{l}\text { DelPozo- } \\
\text { Banos et al., } \\
2021^{21}\end{array}$ & $\begin{array}{l}\text { Primary and } \\
\text { secondary }\end{array}$ & Decrease & Yes & $-40 \%$ & Aug-20 & $-30 \%$ & Mar-21 & $\begin{array}{l}\text { High- } \\
\text { moderate }\end{array}$ & High income \\
\hline 6 & $\begin{array}{l}\text { Gesi et al., } \\
202145\end{array}$ & ED & Decrease & Not reported & $-13 \%$ & Jun-20 & & & Low & High income \\
\hline 7 & $\begin{array}{l}\text { Gonc } \square \text { alves- } \\
\text { Pinho, et al } \\
2020^{46}\end{array}$ & $\begin{array}{l}\text { ED } \\
\text { (psychiatric) }\end{array}$ & Decrease & Not reported & $-56 \%$ & May-20 & & & Low & High income \\
\hline 8 & $\begin{array}{l}\text { Harmon et al., } \\
2021\end{array}$ & ED & Decrease & No & $-26 \%$ & Jun-20 & No change & Nov-20 & Moderate & High income \\
\hline 9 & $\begin{array}{l}\text { Hawton et al., } \\
2021^{48}\end{array}$ & ED & Decrease & Yes & $-37 \%$ & Jun-20 & & & Moderate & High income \\
\hline 10 & $\begin{array}{l}\text { Jollant et al., } \\
2021^{8}\end{array}$ & $\begin{array}{l}\text { Hospital } \\
\text { admissions }\end{array}$ & Decrease & Yes & $-21 \%$ & Aug-20 & & & Moderate & High income \\
\hline 11 & 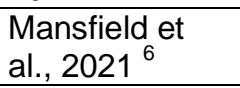 & $\begin{array}{l}\text { Primary and } \\
\text { secondary }\end{array}$ & Decrease & Yes & $-56 \%{ }^{\#}$ & Jul-20 & & & $\begin{array}{l}\text { High/modera } \\
\text { te }\end{array}$ & High income \\
\hline 12 & $\begin{array}{l}\text { Mclntyre et al., } \\
2020^{49}\end{array}$ & $\begin{array}{l}\text { Liaison } \\
\text { psychiatry } \\
\text { referrals }\end{array}$ & Decrease & Not reported & $-8.50 \%$ & May-20 & & & Moderate & High income \\
\hline 13 & $\begin{array}{l}\text { Mourouvaye et } \\
\text { al., } 2020^{28}\end{array}$ & $\begin{array}{l}\text { Children's } \\
\text { hospital }\end{array}$ & Decrease & Yes & $-50 \%$ & Jun-20 & & & Moderate & High income \\
\hline 14 & $\underset{50}{\text { Nuzum, }} 2020$ & ED & Decrease & Not reported & $-34 \%$ & May-20 & & & Moderate & High income \\
\hline
\end{tabular}




\begin{tabular}{|c|c|c|c|c|c|c|c|c|c|c|}
\hline $\begin{array}{l}\text { Stud } \\
\text { y ID }\end{array}$ & Authors & $\begin{array}{l}\text { Healthcare } \\
\text { setting }\end{array}$ & $\begin{array}{l}\text { Increase, } \\
\text { decrease or } \\
\text { no change }\end{array}$ & $\begin{array}{l}\text { Statistically } \\
\text { significant } \\
\text { change? }\end{array}$ & $\begin{array}{l}\text { Approx. \% } \\
\text { change } \\
\text { (95\% Cl if } \\
\text { provided) }\end{array}$ & $\begin{array}{l}\text { Latest } \\
\text { month of } \\
\text { study } \\
\text { period }\end{array}$ & $\begin{array}{l}\text { Change } \\
\text { post- } \\
\text { lockdown } \\
\text { (if studied) }\end{array}$ & $\begin{array}{l}\text { Additional, } \\
\text { post-Sep. } \\
2020 \text { period } \\
\text { examined }\end{array}$ & $\begin{array}{l}\text { Quality of } \\
\text { evidence }\end{array}$ & $\begin{array}{l}\text { Global } \\
\text { setting }\end{array}$ \\
\hline 15 & $\begin{array}{l}\text { Ontiveros et } \\
\text { al., } 2021^{51}\end{array}$ & $\begin{array}{l}\text { Poison } \\
\text { registry }\end{array}$ & Decrease & Yes & $-17 \%$ & May-20 & & & Low & High income \\
\hline 16 & $\begin{array}{l}\text { Pignon et al., } \\
2020^{52}\end{array}$ & $\begin{array}{l}\text { ED } \\
\text { (psychiatric) }\end{array}$ & Decrease & Not reported & $-57 \%$ & Apr-20 & & & Low & High income \\
\hline 17 & $\begin{array}{l}\text { Steeg et al., } \\
20211_{19}\end{array}$ & $\begin{array}{l}\text { Primary and } \\
\text { secondary }\end{array}$ & Decrease & Yes & $\begin{array}{l}-31 \text { to }-41 \% \\
\S\end{array}$ & Apr-20 & $-8 \%$ to $-14 \%$ & May-21 & $\begin{array}{l}\text { High- } \\
\text { moderate }\end{array}$ & High income \\
\hline 18 & $\begin{array}{l}\text { Walker et al., } \\
202053\end{array}$ & ED & Decrease & Not reported & $-39 \%$ & Apr-20 & & & Low & High income \\
\hline 19 & $\begin{array}{l}\text { Yard et al., } \\
2021_{18}\end{array}$ & $\begin{array}{l}\text { ED }(12-25 \\
\text { years) }\end{array}$ & Decrease & Yes & $\begin{array}{l}-17 \% \text { to }- \\
26 \% \text { q }\end{array}$ & Apr-20 & No change & Mar-21 & $\begin{array}{l}\text { High- } \\
\text { moderate }\end{array}$ & High income \\
\hline 20 & $\begin{array}{l}\text { Bothara et al., } \\
2021^{54}\end{array}$ & ED & Increase & Yes & $\mathrm{NA}^{*}$ & Apr-20 & & & Low & High income \\
\hline 21 & $\begin{array}{l}\text { Canzi et al., } \\
2020^{55}\end{array}$ & $\begin{array}{l}\text { Trauma } \\
\text { admissions }\end{array}$ & Increase & Yes & $280 \%$ & May-20 & & & Low & High income \\
\hline 22 & $\begin{array}{l}\text { Gracia et al., } \\
2021\end{array}$ & $\begin{array}{l}\text { Multi-service } \\
\text { ages } 12-18\end{array}$ & Increase & No & $25 \%$ & Mar-21 & $\begin{array}{l}\text { Change } \\
\text { related to } \\
\text { March 2020- } \\
\text { March } 2021\end{array}$ & Mar-21 & Low & High income \\
\hline 23 & $\begin{array}{l}\text { Habu et al., } \\
2021^{57}\end{array}$ & $\begin{array}{l}\text { Ambulance } \\
\text { calls }\end{array}$ & Increase & Not reported & $36 \%$ & Aug-20 & & & Low & High income \\
\hline 24 & $\begin{array}{l}\text { Henry et al., } \\
202158\end{array}$ & ED & Increase & Yes & $10 \%$ & May-20 & & & Low & High income \\
\hline 25 & $\begin{array}{l}\text { Holland et al., } \\
2021^{22}\end{array}$ & ED & Increase & Yes & $6 \%$ & Oct-20 & & & Moderate & High income \\
\hline 26 & $\begin{array}{l}\text { Karakasi et al., } \\
2020^{13}\end{array}$ & $\begin{array}{l}\text { ED } \\
\text { (psychiatric) }\end{array}$ & Increase & Not reported & $40 \%$ & May-20 & & & Low & High income \\
\hline 27 & $\begin{array}{l}\text { Moore et al., } \\
2021^{59}\end{array}$ & $\begin{array}{l}\text { Ambulance } \\
\text { calls }\end{array}$ & Increase & Not reported & $8 \%$ & Jul-20 & & & Low & High income \\
\hline 28 & $\begin{array}{l}\text { Nia et al., } \\
2021\end{array}$ & $\begin{array}{l}\text { Trauma } \\
\text { admissions }\end{array}$ & Increase & Yes & $50 \%$ & Apr-20 & & & Low & High income \\
\hline 29 & $\begin{array}{l}\text { Olding et al., } \\
2021^{14}\end{array}$ & $\begin{array}{l}\text { Trauma } \\
\text { admissions }\end{array}$ & Increase & Not reported & $60 \%$ & Apr-20 & & & Low & High income \\
\hline 30 & $\begin{array}{l}\text { Popp et al., } \\
2021\end{array}$ & $\begin{array}{l}\text { Plastic } \\
\text { surgery }\end{array}$ & Increase & Yes & $\mathrm{NA}^{*}$ & Apr-20 & & & Moderate & High income \\
\hline
\end{tabular}




\begin{tabular}{|c|c|c|c|c|c|c|c|c|c|c|}
\hline $\begin{array}{l}\text { Stud } \\
\text { y ID }\end{array}$ & Authors & $\begin{array}{l}\text { Healthcare } \\
\text { setting }\end{array}$ & $\begin{array}{l}\text { Increase, } \\
\text { decrease or } \\
\text { no change }\end{array}$ & $\begin{array}{l}\text { Statistically } \\
\text { significant } \\
\text { change? }\end{array}$ & $\begin{array}{l}\text { Approx. \% } \\
\text { change } \\
\text { (95\% Cl if } \\
\text { provided) }\end{array}$ & $\begin{array}{l}\text { Latest } \\
\text { month of } \\
\text { study } \\
\text { period }\end{array}$ & $\begin{array}{l}\text { Change } \\
\text { post- } \\
\text { lockdown } \\
\text { (if studied) }\end{array}$ & $\begin{array}{l}\text { Additional, } \\
\text { post-Sep. } \\
2020 \text { period } \\
\text { examined }\end{array}$ & $\begin{array}{l}\text { Quality of } \\
\text { evidence }\end{array}$ & $\begin{array}{l}\text { Global } \\
\text { setting }\end{array}$ \\
\hline 31 & $\begin{array}{l}\text { Rhodes et al., } \\
2020^{15}\end{array}$ & $\begin{array}{l}\text { Trauma } \\
\text { admissions }\end{array}$ & Increase & Not reported & $83 \%$ & Apr-20 & & & Low & High income \\
\hline 32 & $\begin{array}{l}\text { Bruns et al., } \\
2021\end{array}$ & $\begin{array}{l}\text { Children's } \\
\text { trauma } \\
\text { admissions }\end{array}$ & No change & No & & May-20 & & & Low & High income \\
\hline 33 & $\begin{array}{l}\text { Chang et al., } \\
2020\end{array}$ & $\begin{array}{l}\text { Trauma } \\
\text { admissions }\end{array}$ & No change & No & & Mar-20 & & & Low & High income \\
\hline 34 & $\begin{array}{l}\text { Chiba et al., } \\
2021\end{array}$ & $\begin{array}{l}\text { Trauma } \\
\text { admissions }\end{array}$ & No change & No & & Jun-20 & & & Low & High income \\
\hline 35 & $\begin{array}{l}\text { Coates et al., } \\
2021^{65}\end{array}$ & $\begin{array}{l}\text { ED (up to } 19 \\
\text { years) }\end{array}$ & No change & No & & NA & & & Low & High income \\
\hline 36 & $\begin{array}{l}\text { Gil-Jardiné et } \\
\text { al., } 20211^{66}\end{array}$ & $\begin{array}{l}\text { Emergency } \\
\text { health } \\
\text { contact } \\
\text { centre }\end{array}$ & No change & Not reported & & May-20 & & & Low & High income \\
\hline 37 & $\begin{array}{l}\text { Jacob et al., } \\
202067\end{array}$ & $\begin{array}{l}\text { Trauma } \\
\text { admissions }\end{array}$ & No change & Not reported & $36 \%$ & Apr-20 & & & Low & High income \\
\hline 38 & $\begin{array}{l}\text { Joyce et al., } \\
2021\end{array}$ & ED & No change & Not reported & & Apr-20 & & & Moderate & High income \\
\hline 39 & $\begin{array}{l}\text { Page et al., } \\
2021\end{array}$ & ED & No change & No & & Jul-20 & & & Low & High income \\
\hline 40 & $\begin{array}{l}\text { Prados-Ojeda } \\
\text { et al., } 202169\end{array}$ & ED & No change & Not reported & & May-20 & & & Low & High income \\
\hline 41 & $\begin{array}{l}\text { Rajput et al., } \\
202170\end{array}$ & $\begin{array}{l}\text { Trauma } \\
\text { admissions }\end{array}$ & No change & no & & May-20 & & & Low & High income \\
\hline 42 & $\begin{array}{l}\text { Shields et al., } \\
2021^{25}\end{array}$ & ED & No change & No & & May-20 & & & Moderate & High income \\
\hline 43 & $\begin{array}{l}\text { Yeates et al., } \\
2021^{71}\end{array}$ & $\begin{array}{l}\text { Trauma } \\
\text { admissions }\end{array}$ & No change & No & & Jun-20 & & & Low & High income \\
\hline 44 & $\begin{array}{l}\text { Ougrin et al., } \\
2021_{27}\end{array}$ & $\begin{array}{l}\text { ED (up to } 18 \\
\text { years) }\end{array}$ & Decrease & Yes & $-23 \%$ & Apr-20 & & & Moderate & $\begin{array}{l}\text { Middle and } \\
\text { high income }\end{array}$ \\
\hline 45 & $\begin{array}{l}\text { Eray and } \\
\text { Sahin } 2021\end{array}$ & $\begin{array}{l}\text { Children's } \\
\text { hospital }\end{array}$ & Decrease & Not reported & $-57 \%$ & Sep-20 & & & Low & $\begin{array}{l}\text { Upper- } \\
\text { middle }\end{array}$ \\
\hline
\end{tabular}




\begin{tabular}{|c|c|c|c|c|c|c|c|c|c|c|}
\hline $\begin{array}{l}\text { Stud } \\
\text { y ID }\end{array}$ & Authors & $\begin{array}{l}\text { Healthcare } \\
\text { setting }\end{array}$ & $\begin{array}{l}\text { Increase, } \\
\text { decrease or } \\
\text { no change }\end{array}$ & $\begin{array}{l}\text { Statistically } \\
\text { significant } \\
\text { change? }\end{array}$ & $\begin{array}{l}\text { Approx. \% } \\
\text { change } \\
\text { (95\% Cl if } \\
\text { provided) }\end{array}$ & $\begin{array}{l}\text { Latest } \\
\text { month of } \\
\text { study } \\
\text { period }\end{array}$ & $\begin{array}{l}\text { Change } \\
\text { post- } \\
\text { lockdown } \\
\text { (if studied) }\end{array}$ & $\begin{array}{l}\text { Additional, } \\
\text { post-Sep. } \\
2020 \text { period } \\
\text { examined }\end{array}$ & $\begin{array}{l}\text { Quality of } \\
\text { evidence }\end{array}$ & $\begin{array}{l}\text { Global } \\
\text { setting }\end{array}$ \\
\hline & & admissions & & & & & & & & income \\
\hline 46 & $\begin{array}{l}\text { Fidancı et al., } \\
2021\end{array}$ & $\begin{array}{l}\text { Children's } \\
\text { hospital }\end{array}$ & Decrease & Not reported & $-83 \%$ & Oct-20 & & & Low & $\begin{array}{l}\text { Upper- } \\
\text { middle } \\
\text { income }\end{array}$ \\
\hline 47 & $\begin{array}{l}\text { Thongchuam } \\
\text { et al., } 2021^{23}\end{array}$ & $\begin{array}{l}\text { Surgery } \\
\text { following } \\
\text { self- } \\
\text { poisoning }\end{array}$ & Increase & Yes & $55 \%$ & Jun-20 & & & Moderate & $\begin{array}{l}\text { Upper- } \\
\text { middle } \\
\text { income }\end{array}$ \\
\hline 48 & $\begin{array}{l}\text { Stašević- } \\
\text { Karličić et al., } \\
2021^{74}\end{array}$ & $\begin{array}{l}\text { ED } \\
\text { (psychiatric) }\end{array}$ & Increase & Yes & $14 \%$ & Aug-20 & & & Low & $\begin{array}{l}\text { Middle } \\
\text { income }\end{array}$ \\
\hline 49 & $\begin{array}{l}\text { Knipe et al., } \\
2021^{20}\end{array}$ & $\begin{array}{l}\text { Hospital } \\
\text { admissions } \\
\text { (self- } \\
\text { poisoning) }\end{array}$ & Decrease & Yes & $\begin{array}{l}-32 \%(\mathrm{Cl} \\
12 \% \text { to } 48 \%)\end{array}$ & Aug-20 & & & $\begin{array}{l}\text { High- } \\
\text { moderate }\end{array}$ & $\begin{array}{l}\text { Lower- } \\
\text { middle } \\
\text { income }\end{array}$ \\
\hline 50 & $\begin{array}{l}\text { Jhanwar et al., } \\
2020\end{array}$ & ED & Decrease & Yes & $-37 \%$ & Apr-20 & & & Low & $\begin{array}{l}\text { Lower- } \\
\text { middle } \\
\text { income }\end{array}$ \\
\hline 51 & $\begin{array}{l}\text { Shrestha et } \\
\text { al., } 2021\end{array}$ & ED & Increase & Not reported & $44 \%$ & Jun-20 & & & Moderate & $\begin{array}{l}\text { Lower- } \\
\text { middle } \\
\text { income }\end{array}$ \\
\hline
\end{tabular}

*zero at baseline

I $-26 \%$ among ages $12-17$ and by $-17 \%$ among ages $18-25$

\# Difference in weekly contacts per million population

$\S-31 \%$ for all episodes and $-41 \%$ for incident episodes 
medRxiv preprint doi: https://doi.org/10.1101/2022.01.26.22269901; this version posted January 28, 2022. The copyright holder for this preprint (which was not certified by peer review) is the author/funder, who has granted medRxiv a license to display the preprint in perpetuity.

It is made available under a CC-BY-ND 4.0 International license .

References

1. Pierce M, Hope H, Ford T, et al. Mental health before and during the COVID-19 pandemic: a longitudinal probability sample survey of the UK population. The lancet Psychiatry 2020 doi: 10.1016/s2215-0366(20)30308-4

2. Pierce M, McManus S, Hope $\mathrm{H}$, et al. Mental health responses to the COVID-19 pandemic: a latent class trajectory analysis using longitudinal UK data. The lancet Psychiatry 2021 doi: 10.1016/s2215-0366(21)00151-6

3. Kola L, Kohrt BA, Hanlon C, et al. COVID-19 mental health impact and responses in lowincome and middle-income countries: reimagining global mental health. Lancet Psychiatry 2021;8(6):535-50. doi: 10.1016/s2215-0366(21)00025-0

4. Xiong J, Lipsitz O, Nasri F, et al. Impact of COVID-19 pandemic on mental health in the general population: A systematic review. Journal of affective disorders 2020;277:5564. doi: 10.1016/j.jad.2020.08.001

5. John A, Okolie C, Eyles E, et al. The impact of the COVID-19 pandemic on self-harm and suicidal behaviour: a living systematic review [version 1; peer review: 1 approved]. 2020. https://f1000research.com/articles/9-1097/v1 (accessed 23 November 2020).

6. Mansfield KE, Mathur R, Tazare J, et al. Indirect acute effects of the COVID-19 pandemic on physical and mental health in the UK: a population-based study. The Lancet Digital health 2021 doi: 10.1016/s2589-7500(21)00017-0

7. Carr MJ, Steeg S, Webb RT, et al. Effects of the COVID-19 pandemic on primary carerecorded mental illness and self-harm episodes in the UK: a population-based cohort study. The Lancet Public health 2021 doi: 10.1016/s2468-2667(20)30288-7

8. Jollant F, Roussot A, E. C, et al. Hospitalization for self-harm during the early months of the COVID-19 pandemic in France: A nationwide retrospective observational cohort study. Lancet Regional Health - Europe 2021; 6.

9. Organisation for Economic Co-operation and Development and World Health Organization. Health at a Glance: Asia/Pacific 2020. MEASURING PROGRESS TOWARDS UNIVERSAL HEALTH COVERAGE 2020 [Available from: https://www.oecdilibrary.org/docserver/26b007cden. pdf?expires=1636987313\&id=id\&accname=guest \&checksum=42A28600012E42C B1F671CB5E53DE3F6 accessed 12.15.2021.

10. Knipe $D$, John A, Padmanathan $P$, et al. Suicide and self-harm in low- and middleincome countries during the COVID-19 pandemic: A systematic review. medRxiv 2021. https://doi.org/10.1101/2021.09.03.21263083.

11. John A, McGuinness L, Okolie C, et al. The impact of the COVID-19 pandemic on selfharm and suicidal behaviour: protocol for a living systematic review [version 1; peer review: 1 approved, 1 approved with reservations]. F1000Resesarch 2020; 9.

12. John A, Webb R, Okolie C, et al. The impact of the COVID-19 pandemic on self-harm and suicidal behaviour: update of living systematic review [version 2; peer review: 1 approved, 2 approved with reservations] . F1000Research 2021; 9(1097). https://doi.org/10.12688/f1000research.25522.2 (accessed 10.08.2021).

13. Karakasi M-V, Zaoutsou A, Theofilidis A, et al. Impact of theSARS-CoV-2 pandemic on psychiatric emergencies in northern Greece: Preliminary study on a sample of the Greek population. Psychiatry and Clinical Neurosciences 2020;74(11):613-15. doi: 10.1111/pen.13136 
medRxiv preprint doi: https://doi.org/10.1101/2022.01.26.22269901; this version posted January 28, 2022. The copyright holder for this preprint (which was not certified by peer review) is the author/funder, who has granted medRxiv a license to display the preprint in perpetuity. It is made available under a CC-BY-ND 4.0 International license .

14. Olding J, Zisman S, Olding C, et al. Penetrating trauma during a global pandemic: Changing patterns in interpersonal violence, self-harm and domestic violence in the Covid-19 outbreak. Surgeon-Journal of the Royal Colleges of Surgeons of Edinburgh and Ireland 2021;19(1):E9-E13. doi: 10.1016/j.surge.2020.07.004

15. Rhodes HX, Petersen K, Biswas S. Trauma Trends During the Initial Peak of the COVID-19 Pandemic in the Midst of Lockdown: Experiences From a Rural Trauma Center. Cureus 2020;12(8) doi: 10.7759/cureus.9811

16. Page MJ, McKenzie JE, Bossuyt PM, et al. The PRISMA 2020 statement: An updated guideline for reporting systematic reviews. Plos Medicine 2021;18(3) doi: 10.1371/journal.pmed.1003583

17. National Institute for Health NH, Lung, and Blood Institute. Quality assessment tool for before-after (pre-post) studies with no control group 2021 [Available from: https://www.nhlbi.nih.gov/health-topics/study-quality-assessment-tools accessed 19.05.2021.

18. Yard E, Radhakrishnan L, Ballesteros MF, et al. Emergency Department Visits for Suspected Suicide Attempts Among Persons Aged 12-25 Years Before and During the COVID-19 Pandemic - United States, January 2019-May 2021. MMWR Morbidity and Mortality Weekly Report 2021;70(24):888-94. doi: 10.15585/mmwr.mm7024e1

19. Steeg S, Bojanic L, Tilston G, et al. Temporal trends in primary care-recorded self-harm during and beyond the first year of the COVID-19 pandemic: Time series analysis of electronic healthcare records for 2.8 million patients in the Greater Manchester Care Record. EClinicalMedicine 2021;41:101175-75. doi: 10.1016/j.eclinm.2021.101175

20. Knipe D, Silva T, Aroos A, et al. Hospital presentations for self-poisoning during COVID-19 in Sri Lanka: an interrupted time-series analysis. The Lancet Psychiatry 2021 doi: 10.1016/S2215-0366(21)00242-X

21. DelPozo-Banos $M$, Lee SC, Friedmann $Y$, et al. Healthcare presentations with self-harm and the association with COVID-19: an e-cohort whole-population-based study using individual-level linked routine electronic health records in Wales, UK, 2016 - March 2021. medRxiv 2021 doi: 10.1101/2021.08.13.21261861

22. Holland KM, Jones C, Vivolo-Kantor AM, et al. Trends in US Emergency Department Visits for Mental Health, Overdose, and Violence Outcomes Before and During the COVID19 Pandemic. JAMA psychiatry 2021 doi: 10.1001/jamapsychiatry.2020.4402

23. Thongchuam C, Mahawongkajit $P$, Kanlerd A. The Effect of the COVID-19 on Corrosive Ingestion in Thailand. Open Access Emergency Medicine 2021;Volume 13:299-304. doi: $10.2147 / O A E M . S 321218$

24. Joyce LR, Richardson SK, McCombie A, et al. Mental health presentations to Christchurch Hospital Emergency Department during COVID-19 lockdown. Emergency Medicine Australasia 2021;33(2):324-30. doi: 10.1111/1742-6723.13667

25. Shields C, Bernard J, Mirza OI, et al. Covid-19, Lockdown and Self-Isolation: Evaluation of Deliberate Self-Harm Admissions. Frontiers in Psychiatry 2021;12 doi: 10.3389/fpsyt.2021.662885

26. Shrestha R, Siwakoti S, Singh S, et al. Impact of the COVID-19 pandemic on suicide and self-harm among patients presenting to the emergency department of a teaching hospital in Nepal. Plos One 2021;16(4) doi: 10.1371/journal.pone.0250706

27. Ougrin $\mathrm{D}$, Wong BH-C, Vaezinejad $\mathrm{M}$, et al. Pandemic-related emergency psychiatric presentations for self-harm of children and adolescents in 10 countries (PREP-kids): a 
medRxiv preprint doi: https://doi.org/10.1101/2022.01.26.22269901; this version posted January 28, 2022. The copyright holder for this preprint (which was not certified by peer review) is the author/funder, who has granted medRxiv a license to display the preprint in perpetuity.

It is made available under a CC-BY-ND 4.0 International license .

retrospective international cohort study. European Child \& Adolescent Psychiatry 2021 doi: 10.1007/s00787-021-01741-6

28. Mourouvaye $M$, Bottemanne $H$, Bonny $G$, et al. Association between suicide behaviours in children and adolescents and the COVID-19 lockdown in Paris, France: a retrospective observational study. Archives of disease in childhood 2020 doi: 10.1136/archdischild-2020-320628

29. Figueroa JP, Bottazzi ME, Hotez $P$, et al. Urgent needs of low-income and middle-income countries for COVID-19 vaccines and therapeutics. Lancet 2021;397(10274):562-64. doi: 10.1016/s0140-6736(21)00242-7

30. Saha S, Tanmoy AM, Tanni AA, et al. New waves, new variants, old inequity: a continuing COVID-19 crisis. Bmj Global Health 2021;6(8) doi: 10.1136/bmjgh-2021-007031

31. Kola L. Global mental health and COVID-19. Lancet Psychiatry 2020;7(8):655-57. doi: $10.1016 / \mathrm{s} 2215-0366(20) 30235-2$

32. Reuters. Europe becomes COVID-19's epicentre again, some countries look at fresh curbs 2021 [Available from: https://www.reuters.com/world/europe/covid-19sepicentre-again-europe-faces-fresh-reckoning-2021-11-12/ accessed 12.11.2012.

33. Jehanzeb S, Suleman M, Tumelty E, et al. The impact of first COVID-19 peak on patient referrals to Liaison Psychiatry Service and staff perception about service provision in Birmingham and Solihull Mental Health Trust Birmingham - a service evaluation project. Bjpsych Open 2021;7:S329-S29. doi: 10.1192/bjo.2021.865

34. Mukadam N, Sommerlad A, Wright J, et al. Acute mental health presentations before and during the COVID-19 pandemic. BJPsych Open 2021;7(4) doi:

10.1192/bjo.2021.970

35. UK Government. Preventing suicide in England: Fifth progress report of the crossgovernment outcomes strategy to save lives 2021.

https://assets.publishing.service.gov.uk/government/uploads/system/uploads/attac hment data/file/973935/fifth-suicide-prevention-strategy-progress-report.pdf (accessed 17.05.2021).

36. Kapur N, Cooper J, O'Connor RC, et al. Non-suicidal self-injury v. attempted suicide: new diagnosis or false dichotomy? British Journal of Psychiatry 2013;202(5):326-28. doi: 10.1192/bjp.bp.112.116111

37. NICE. Self-harm: Longer-term management. Evidence update April 2013. Evidence update 39: National Collaborating Centre for Mental Health, 2013.

38. World Health Organization. Preventing suicide: A global imperative. 2014. http://www.who.int/mental health/suicide-prevention/world report 2014/en/ (accessed 26/11/2019).

39. Sveticic J, Stapelberg NJC, Turner K. Suicide prevention during COVID-19: identification of groups with reduced presentations to emergency departments. Australasian Psychiatry 2021 doi: 10.1177/1039856221992632

40. Sokoloff WC, Krief WI, Giusto KA, et al. Pediatric emergency department utilization during the COVID-19 pandemic in New York City. The American journal of emergency medicine 2021;45:100-04. doi: 10.1016/j.ajem.2021.02.029

41. McNicholas F, Kelleher I, Hedderman E, et al. Referral patterns for specialist child and adolescent mental health services in the Republic of Ireland during the COVID-19 pandemic compared with 2019 and 2018. Bjpsych Open 2021;7(3) doi:

$10.1192 /$ bjo. 2021.48 
medRxiv preprint doi: https://doi.org/10.1101/2022.01.26.22269901; this version posted January 28, 2022. The copyright holder for this preprint (which was not certified by peer review) is the author/funder, who has granted medRxiv a license to display the preprint in perpetuity.

It is made available under a CC-BY-ND 4.0 International license .

42. Capuzzi E, Di Brita C, Caldiroli A, et al. Psychiatric emergency care during Coronavirus 2019 (COVID 19) pandemic lockdown: results from a Department of Mental Health and Addiction of northern Italy. Psychiatry Research 2020;293 doi:

10.1016/j.psychres.2020.113463

43. Chen S, Jones PB, Underwood BR, et al. The early impact of COVID-19 on mental health and community physical health services and their patients' mortality in Cambridgeshire and Peterborough, UK. Journal of psychiatric research 2020;131:24454. doi: 10.1016/j.jpsychires.2020.09.020

44. Dragovic M, Pascu V, Hall T, et al. Emergency department mental health presentations before and during the COVID-19 outbreak in Western Australia. Australasian Psychiatry 2020;28(6):627-31. doi: 10.1177/1039856220960673

45. Gesi C, Grasso F, Dragogna F, et al. How Did COVID-19 Affect Suicidality? Data from a Multicentric Study in Lombardy. Journal of Clinical Medicine 2021;10(11):2410. doi: 10.3390/jcm10112410

46. Goncalves-Pinho M, Mota P, Ribeiro J, et al. The Impact of COVID-19 Pandemic on Psychiatric Emergency Department Visits - A Descriptive Study. The Psychiatric quarterly 2020 doi: 10.1007/s11126-020-09837-z

47. Harmon KJ, Fliss MD, Marshall SW, et al. The impact of the COVID-19 pandemic on the utilization of emergency department services for the treatment of injuries. The American Journal of Emergency Medicine 2021;47:187-91. doi: 10.1016/j.ajem.2021.04.019

48. Hawton K, Casey D, Bale E, et al. Self-harm during the early period of the COVID-19 pandemic in England: Comparative trend analysis of hospital presentations. Journal of Affective Disorders 2021;282:991-95. doi: 10.1016/j.jad.2021.01.015

49. McIntyre A, Tong K, McMahon E, et al. COVID-19 and its effect on emergency presentations to a tertiary hospital with self-harm in Ireland. Irish journal of psychological medicine 2020:1-7. doi: 10.1017/ipm.2020.116

50. Nuzum E, Martin, E., Morgan, G., Dutta, R., Mueller, C., Polling, C., Pritchard, M., Velupillai, S., Stewart, R. Self-harm presentations to Emergency Departments and Place of Safety during the 'first wave' of the UK COVID-19 pandemic: South London and Maudsley data on service use from February to June 2020. medRxiv 2020;doi: https://doi.org/10.1101/2020.12.10.20247155

51. Ontiveros ST, Levine MD, Cantrell FL, et al. Despair in the time of COVID: A look at suicidal ingestions reported to the California Poison Control System during the pandemic. Academic Emergency Medicine 2021;28(3):300-05. doi: 10.1111/acem.14209

52. Pignon B, Gourevitch R, Tebeka S, et al. Dramatic reduction of psychiatric emergency consultations during lockdown linked toCOVID-19 in Paris and suburbs. Psychiatry and Clinical Neurosciences 2020;74(10):557-59. doi: 10.1111/pcn.13104

53. Walker LE, Heaton HA, Monroe RJ, et al. Impact of the SARS-CoV-2 Pandemic on Emergency Department Presentations in an Integrated Health System. Annals of Emergency Medicine 2020;76(4):S2-S3.

54. Bothara RK, Raina A, Carne B, et al. Paediatric presentations to Christchurch Hospital Emergency Department during COVID-19 lockdown. Journal of Paediatrics and Child Health doi: 10.1111/jpc.15347 
medRxiv preprint doi: https://doi.org/10.1101/2022.01.26.22269901; this version posted January 28, 2022. The copyright holder for this preprint (which was not certified by peer review) is the author/funder, who has granted medRxiv a license to display the preprint in perpetuity.

It is made available under a CC-BY-ND 4.0 International license .

55. Canzi G, De Ponti E, Corradi F, et al. Epidemiology of Maxillo-Facial Trauma During COVID-19 Lockdown: Reports From the Hub Trauma Center in Milan.

Craniomaxillofacial Trauma \& Reconstruction 2020 doi: 10.1177/1943387520983119

56. Gracia R, Pamias M, Mortier $P$, et al. Is the COVID-19 pandemic a risk factor for suicide attempts in adolescent girls? Journal of Affective Disorders 2021;292:139-41. doi: 10.1016/j.jad.2021.05.044

57. Habu H, Takao S, Fujimoto R, et al. Emergency Dispatches for Suicide Attempts During the COVID-19 Outbreak in Okayama, Japan: A Descriptive Epidemiological Study. Journal of Epidemiology 2021;31(9):511-17. doi: 10.2188/jea.JE20210066

58. Henry N, Parthiban S, Farroha A. The effect of COVID-19 lockdown on the incidence of deliberate self-harm injuries presenting to the emergency room. International Journal of Psychiatry in Medicine 2021;56(4):266-77. doi: 10.1177/0091217420982100

59. Moore HE, Siriwardena AN, Gussy M, et al. Mental health emergencies and COVID-19: the impact of 'lockdown' in the East Midlands of the UK. BJPsych Open 2021;7(4) doi: 10.1192/bjo.2021.973

60. Nia A, Popp D, Diendorfer C, et al. Impact of lockdown during the COVID-19 pandemic on number of patients and patterns of injuries at a level I trauma center. Wiener Klinische Wochenschrift 2021;133(7-8):336-43. doi: 10.1007/s00508-021-01824-z

61. Popp D, Smolle C, Nischwitz SP, et al. COVID-19 and plastic surgery: aesthetic surgery or essential medical care? Impact of the COVID-19 pandemic on patient care in the plastic surgery department at an university hospital. Handchirurgie Mikrochirurgie Plastische Chirurgie 2021;53(02):185-93. doi: 10.1055/a-1308-2638

62. Bruns N, Willemsen L, Holtkamp K, et al. Trends in accident-related admissions to pediatric intensive care units during the first COVID-19 lockdown in Germany. medRxiv 2021 doi: 10.1101/2021.08.06.21261728

63. Chang Y, KM. K, Kim H, et al. Impacts of Social Distancing During the COVID-19 Outbreaks in Korea: Level 1 Trauma Center Data of Domestic Incidents and Intentional Injury. Osong Public Health and Research Perspectives 2020; 11(6).

64. Chiba H, Lewis M, Benjamin ER, et al. "Safer at home": The effect of the COVID-19 lockdown on epidemiology, resource utilization, and outcomes at a large urban trauma center. Journal of Trauma and Acute Care Surgery 2021;90(4):708-13. doi: 10.1097/ta.0000000000003061

65. Coates L, Marshall R, Johnson K, et al. Mental Health Utilization in Children in the time of COVID-19. medRxiv 2021 doi: 10.1101/2021.08.11.21261712

66. Gil-Jardiné $C$, Chenais G, Pradeau C, et al. Trends in reasons for emergency calls during the COVID-19 crisis in the department of Gironde, France using artificial neural network for natural language classification. Scandinavian Journal of Trauma, Resuscitation and Emergency Medicine 2021;29(1) doi: 10.1186/s13049-021-00862w

67. Jacob S, Mwagiru D, Thakur I, et al. Impact of societal restrictions and lockdown on trauma admissions during theCOVID-19 pandemic: a single-centre cross-sectional observational study. Anz Journal of Surgery 2020;90(11):2227-31. doi: 10.1111/ans.16307

68. Page A, Bandara P, Hammond TE, et al. Impact of Covid-19 physical distancing policies on incidence of intentional self-harm in Western Sydney. Australasian Psychiatry 2021:103985622110108. doi: 10.1177/10398562211010808 
medRxiv preprint doi: https://doi.org/10.1101/2022.01.26.22269901; this version posted January 28, 2022. The copyright holder for this preprint (which was not certified by peer review) is the author/funder, who has granted medRxiv a license to display the preprint in perpetuity.

It is made available under a CC-BY-ND 4.0 International license .

69. Prados-Ojeda JL, Gordillo-Urbano RM, Carrillo-Perez T, et al. Suicide Presentations to an Emergency Department Pre and During the COVID Lockdown, March-May 2020, in Spain. Archives of Suicide Research 2021 doi: 10.1080/13811118.2021.1887023

70. Rajput K, Sud A, Rees M, et al. Epidemiology of trauma presentations to a major trauma centre in the North West of England during the COVID-19 level 4 lockdown.

European Journal of Trauma and Emergency Surgery 2021;47(3):631-36. doi: 10.1007/s00068-020-01507-w

71. Yeates EO, Grigorian A, Barrios C, et al. Changes in traumatic mechanisms of injury in Southern California related to COVID-19: Penetrating trauma as a second pandemic. Journal of Trauma and Acute Care Surgery 2021;90(4):714-21. doi: 10.1097/ta.0000000000003068

72. Eray S, Sahin V. Covid-19 Pandemic may have Unique Effects on Emergency Admissions for Pediatric Psychopathology: A Single-Center Study. Psychiatry and Behavioral Sciences 2021;11(2):1. doi: 10.5455/PBS.20210329114825

73. Fidancı I, Taşar MA, Akıntuğ B, et al. The impact of the COVID-19 pandemic on paediatric emergency service. International Journal of Clinical Practice 2021;75(9) doi: 10.1111/ijcp.14398

74. Stasevic-Karlicic I, Djordjevic V, Dutina A, et al. The impact of COVID-19 pandemic on suicide attempts in the Republic of Serbia. Srpski Arhiv Za Celokupno Lekarstvo 2021;149(7-8):455-60. doi: 10.2298/sarh210506053s

75. Mclntyre A, Tong K, McMahon E, et al. COVID-19 and its effect on emergency presentations to a tertiary hospital with self-harm in Ireland. Irish Journal of Psychological Medicine 2021;38(2):116-22. doi: 10.1017/ipm.2020.116

76. Nuzum EM, E. Morgan, G. Dutta, R. Mueller, C. Polling, C. Pritchard, M. Velupillai, S. Stewart, R. Self-harm presentations to Emergency Departments and Place of Safety during the 'first wave' of the UK COVID-19 pandemic: South London and Maudsley data on service use from February to June 2020. medRxiv 2020; doi: https://doi.org/10.1101/2020.12.10.20247155

77. Walker LE, Heaton HA, Monroe RJ, et al. Impact of the SARS-CoV-2 Pandemic on Emergency Department Presentations in an Integrated Health System. Mayo Clinic Proceedings 2020;95(11):2395-407. doi: 10.1016/j.mayocp.2020.09.019

78. Chang Y, KM. K, Kim H, et al. Impacts of Social Distancing During the COVID-19 Outbreaks in Korea: Level 1 Trauma Center Data of Domestic Incidents and Intentional Injury Osong Public Health and Research Perspectives 2020; 11(6).

79. Jhanwar S, Krishnan V, Rohilla J. Consultation-Liaison Psychiatry During COVID-19 Lockdown: A Retrospective Chart Review. Cureus 2020;12(10) doi:

10.7759/cureus.11048 
Supplement 1: Table S1: Details of included studies: $1^{\text {st }}$ Jan. 2020 to $7^{\text {th }}$ Sep. 2021

\begin{tabular}{|c|c|c|c|c|c|c|c|}
\hline Authors & $\begin{array}{l}\text { Report } \\
\text { type }\end{array}$ & $\begin{array}{l}\text { Country } \\
\text { (region) of } \\
\text { study setting }\end{array}$ & $\begin{array}{l}\text { Study design and data } \\
\text { used }\end{array}$ & Outcome & Findings & $\begin{array}{l}\text { Comments/limitatio } \\
\text { ns including } \\
\text { considerations } \\
\text { from JBI checklist }\end{array}$ & $\begin{array}{l}\text { Quality } \\
\text { rating of } \\
\text { evidence } \\
\text { relating } \\
\text { specifically } \\
\text { to self- } \\
\text { harm }^{1}\end{array}$ \\
\hline $\begin{array}{l}\text { 1. Capuzz } \\
\text { i et al., } \\
2020{ }^{42}\end{array}$ & $\begin{array}{l}\text { Peer- } \\
\text { reviewed } \\
\text { article }\end{array}$ & Italy (Lombardy) & $\begin{array}{l}\text { Emergency psychiatric } \\
\text { evaluations, including 'self- } \\
\text { harm/suicide' attempts as a } \\
\text { separate category, at } \\
\text { psychiatric emergency rooms } \\
\text { in two centres in Lombardy } \\
\text { were compared in two } \\
\text { equivalent periods pre- } \\
\text { COVID-19 ( } 22 \text { Feb } 2019-5 \\
\text { May 2019) and following the } \\
\text { first COVID-19 case in Italy } \\
\text { up to end of first phase of } \\
\text { lock-down (21 Feb } 2020 \text { to } 3 \\
\text { May 2020). Data were } \\
\text { obtained from hospital } \\
\text { registers. }\end{array}$ & $\begin{array}{l}\text { Psychiatric } \\
\text { emergency } \\
\text { department } \\
\text { consultations } \\
\text { for suicide } \\
\text { attempt/self- } \\
\text { harm. }\end{array}$ & $\begin{array}{l}\text { In period A (2019) } \\
\text { there were } \\
68 \text { attendances } \\
(17.5 \%) \text { for self- } \\
\text { harm/suicide attempt } \\
\text { compared to } 59 \text { in } \\
\text { period B (2020). } \\
\text { The rate of self-harm } \\
\text { consultations as a } \\
\text { proportion of all } \\
\text { consultations was } \\
\text { higher during the } \\
\text { COVID-19 period. }\end{array}$ & $\begin{array}{l}\text { Low numbers of self- } \\
\text { harm/suicide } \\
\text { attempts included in } \\
\text { the study. } \\
\text { No definition of self- } \\
\text { harm/suicide attempt } \\
\text { was provided. } \\
\text { Limited information } \\
\text { about the methods } \\
\text { for extracting data } \\
\text { from electronic } \\
\text { health records. } \\
\text { Significance testing } \\
\text { was only conducted } \\
\text { for differences in } \\
\text { self-harm as a } \\
\text { proportion of total } \\
\text { attendances, not for } \\
\text { differences between } \\
\text { absolute numbers. }\end{array}$ & Low \\
\hline $\begin{array}{l}\text { 2. Carr, } \\
\text { Steeg } \\
\text { et al. } \\
2021^{7}\end{array}$ & $\begin{array}{l}\text { Peer- } \\
\text { reviewed } \\
\text { article }\end{array}$ & UK (nationwide) & $\begin{array}{l}\text { Anonymised patient data } \\
\text { from primary care records of } \\
\text { patients from } 1697 \text { UK } \\
\text { general practices registered } \\
\text { in the Clinical Practice } \\
\text { Research Datalink were }\end{array}$ & $\begin{array}{l}\text { Primary care- } \\
\text { recorded } \\
\text { self-harm }\end{array}$ & $\begin{array}{l}\text { The incidence of self- } \\
\text { harm was } 37.6 \% \\
\text { lower than expected } \\
\text { in April, } 2020 \\
\text { compared to } \\
\text { expected rates and }\end{array}$ & $\begin{array}{l}\text { The self-harm } \\
\text { outcome was based } \\
\text { on a broad definition } \\
\text { which included } \\
\text { episodes of varying } \\
\text { suicidal intent. }\end{array}$ & $\begin{array}{l}\text { High/moder } \\
\text { ate }\end{array}$ \\
\hline
\end{tabular}




\begin{tabular}{|c|c|c|c|c|c|c|c|}
\hline Authors & $\begin{array}{l}\text { Report } \\
\text { type }\end{array}$ & $\begin{array}{l}\text { Country } \\
\text { (region) of } \\
\text { study setting }\end{array}$ & $\begin{array}{l}\text { Study design and data } \\
\text { used }\end{array}$ & Outcome & Findings & $\begin{array}{l}\text { Comments/limitatio } \\
\text { ns including } \\
\text { considerations } \\
\text { from JBI checklist }\end{array}$ & $\begin{array}{l}\text { Quality } \\
\text { rating of } \\
\text { evidence } \\
\text { relating } \\
\text { specifically } \\
\text { to self- } \\
\text { harm }^{1}\end{array}$ \\
\hline & & & $\begin{array}{l}\text { included. Monthly incident } \\
\text { and total episodes of primary } \\
\text { care recorded self-harm for } \\
\text { the period March-September } \\
2020 \text { were compared to } \\
\text { expected counts based on } \\
\text { data from } 1 \text { January } 2010 \text { to } \\
29^{\text {th }} \text { February } 2020 \text {. }\end{array}$ & & $\begin{array}{l}\text { the all episode event } \\
\text { rate was } 36.6 \% \\
\text { lower. } \\
\text { In April } 2020 \text {, } \\
\text { incidence and event } \\
\text { rates } \\
\text { for self-harm were } \\
\text { substantially lower } \\
\text { than expected for } \\
\text { women and people } \\
\text { aged below } 45 \text { years. } \\
\text { Self-harm incidence } \\
\text { increased from } \\
\text { August } 2020 \text {, in the } \\
\text { 10-17-year age } \\
\text { group. }\end{array}$ & $\begin{array}{l}\text { It is not known how } \\
\text { many of the primary } \\
\text { care recorded self- } \\
\text { harm episodes had } \\
\text { resulted in hospital } \\
\text { presentations. }\end{array}$ & \\
\hline $\begin{array}{l}\text { 3. Chen } \\
\text { et al., } \\
2020\end{array}$ & $\begin{array}{l}\text { Peer- } \\
\text { reviewed } \\
\text { article }\end{array}$ & $\begin{array}{l}\text { England } \\
\text { (Cambridge) }\end{array}$ & $\begin{array}{l}\text { Data were obtained from } \\
\text { hospital clinical } \\
\text { record systems. People } \\
\text { using or referred to inpatient } \\
\text { and community mental health } \\
\text { services (including } \\
\text { psychological therapy } \\
\text { services) from liaison } \\
\text { psychiatry in Cambridge and } \\
\text { Peterborough. The study } \\
\text { period included } 11 \text { March } \\
2014-30 \text { August } 2020, \text { with } \\
23 \text { March } 2020 \text { used as the } \\
\text { event date for interrupted }\end{array}$ & $\begin{array}{l}\text { Number of } \\
\text { referrals } \\
\text { following } \\
\text { presenting } \\
\text { problems } \\
\text { involving } \\
\text { intentional } \\
\text { drug } \\
\text { overdose } \\
\text { and other } \\
\text { forms of self- } \\
\text { harm }\end{array}$ & $\begin{array}{l}\text { A marked reduction } \\
(p<0.001) \text { in liaison } \\
\text { psychiatry referrals } \\
\text { following intentional } \\
\text { drug overdose and } \\
\text { self-harm occurred } \\
\text { after } 23 \text { March } 2020 \text {. } \\
\text { The percentage } \\
\text { reduction was not } \\
\text { specified. }\end{array}$ & $\begin{array}{l}\text { Liaison team } \\
\text { referrals only (not all } \\
\text { ED } \\
\text { attendances) at a } \\
\text { single hospital. } \\
\text { Liaison psychiatry } \\
\text { referral pathways } \\
\text { may have changed } \\
\text { as a result of } \\
\text { COVID-19. } \\
\text { Seasonal trends } \\
\text { were accounted for } \\
\text { in the analysis. }\end{array}$ & Moderate \\
\hline
\end{tabular}




\begin{tabular}{|c|c|c|c|c|c|c|c|}
\hline Authors & $\begin{array}{l}\text { Report } \\
\text { type }\end{array}$ & $\begin{array}{l}\text { Country } \\
\text { (region) of } \\
\text { study setting }\end{array}$ & $\begin{array}{l}\text { Study design and data } \\
\text { used }\end{array}$ & Outcome & Findings & $\begin{array}{l}\text { Comments/limitatio } \\
\text { ns including } \\
\text { considerations } \\
\text { from JBI checklist }\end{array}$ & $\begin{array}{l}\text { Quality } \\
\text { rating of } \\
\text { evidence } \\
\text { relating } \\
\text { specifically } \\
\text { to self- } \\
\text { harm }^{1}\end{array}$ \\
\hline & & & time series analysis. & & & & \\
\hline $\begin{array}{l}\text { 4. Dragovi } \\
\text { c et al., } \\
202044\end{array}$ & $\begin{array}{l}\text { Peer- } \\
\text { reviewed } \\
\text { article }\end{array}$ & $\begin{array}{l}\text { Australia } \\
\text { (Western } \\
\text { Australia) }\end{array}$ & $\begin{array}{l}\text { Data from three EDs were } \\
\text { extracted from the Western } \\
\text { Australia North Metropolitan } \\
\text { Health Services Emergency } \\
\text { Department Data Collection } \\
\text { database. } \\
\text { Attendances over the period } \\
\text { January to May } 2020 \text { were } \\
\text { compared to those that } \\
\text { occurred over the same } \\
\text { calendar month during } 2019 \text {. }\end{array}$ & $\begin{array}{l}\text { Numbers of } \\
\text { ED } \\
\text { presentations } \\
\text { for suicidal } \\
\text { and self- } \\
\text { harm } \\
\text { behaviour. }\end{array}$ & $\begin{array}{l}\text { Suicidality and self- } \\
\text { harm presentations } \\
\text { decreased by } 26 \% \text {, } \\
\text { from } 269 \text { in the } 2019 \\
\text { study period to } 199 \\
\text { in } 2020(p<0.001) \text {. }\end{array}$ & $\begin{array}{l}\text { The data collection } \\
\text { methods lack } \\
\text { contextual detail. The } \\
\text { authors do not } \\
\text { describe the } \\
\text { behaviours included } \\
\text { as 'suicidal and self- } \\
\text { harm behaviours', } \\
\text { though state that } \\
\text { ICD-10 psychiatric } \\
\text { diagnoses codes } \\
\text { were used. }\end{array}$ & Moderate \\
\hline $\begin{array}{l}\text { 5. DelPoz } \\
\text { O- } \\
\text { Banos, } \\
\text { Lee et } \\
\text { al. } \\
2021^{21}\end{array}$ & Preprint & $\begin{array}{l}\text { Wales } \\
\text { (nationwide) }\end{array}$ & $\begin{array}{l}\text { An existing databank of } \\
\text { individual-level, linkable } \\
\text { electronic health records } \\
\text { from primary care, ED and } \\
\text { hospital data was utilised. } \\
\text { Weekly healthcare contacts } \\
\text { for self-harm were compared } \\
\text { between Wave } 1 \text { ( } 9^{\text {th }} \text { March } \\
\left.2020 \text { to } 16^{\text {th }} \text { August } 2020\right) \\
\text { and Wave } 2\left(17^{\text {th }} \text { August }\right. \\
\left.2020 \text { to } 14^{\text {th }} \text { March } 2021\right) \\
\text { and the equivalent calendar } \\
\text { periods in } 2016 \text { to } 2019 \text {. }\end{array}$ & $\begin{array}{l}\text { Number of } \\
\text { self-harm } \\
\text { contacts } \\
\text { including } \\
\text { primary care } \\
\text { consultations } \\
\text {, ED } \\
\text { presentations } \\
\text { and hospital } \\
\text { admissions. }\end{array}$ & $\begin{array}{l}\text { Across all healthcare } \\
\text { settings, weekly self- } \\
\text { harm contacts } \\
\text { reduced by around } \\
40 \% \text { in Wave } 1 \\
\text { compared to the } \\
\text { equivalent periods in } \\
2016 \text { to } 2019 \text {. Levels } \\
\text { returned to before } \\
\text { COVID-19 levels by } \\
\text { July-August } 2020, \\
\text { and in Wave } 2 \\
\text { reduced by around } \\
30 \% \text {. } \\
\text { Disproportionate } \\
\text { reductions in primary } \\
\text { care contacts for }\end{array}$ & $\begin{array}{l}\text { Nationwide } \\
\text { coverage. } \\
\text { Fluctuations in } \\
\text { previous years were } \\
\text { accounted for in the } \\
\text { trends during the } \\
\text { COVID-19 periods. } \\
\text { Multiple healthcare } \\
\text { settings were } \\
\text { examined. }\end{array}$ & $\begin{array}{l}\text { High/moder } \\
\text { ate }\end{array}$ \\
\hline
\end{tabular}




\begin{tabular}{|c|c|c|c|c|c|c|c|}
\hline Authors & $\begin{array}{l}\text { Report } \\
\text { type }\end{array}$ & $\begin{array}{l}\text { Country } \\
\text { (region) of } \\
\text { study setting }\end{array}$ & $\begin{array}{l}\text { Study design and data } \\
\text { used }\end{array}$ & Outcome & Findings & $\begin{array}{l}\text { Comments/limitatio } \\
\text { ns including } \\
\text { considerations } \\
\text { from JBI checklist }\end{array}$ & $\begin{array}{l}\text { Quality } \\
\text { rating of } \\
\text { evidence } \\
\text { relating } \\
\text { specifically } \\
\text { to self- } \\
\text { harm }^{1}\end{array}$ \\
\hline & & & & & $\begin{array}{l}\text { self-harm were } \\
\text { observed. } \\
\text { Similar patterns were } \\
\text { seen in each setting. }\end{array}$ & & \\
\hline $\begin{array}{l}\text { 6. Gesi, } \\
\text { Grasso } \\
\text { et al. } \\
2021{ }^{45}\end{array}$ & $\begin{array}{l}\text { Peer- } \\
\text { reviewed } \\
\text { article }\end{array}$ & Italy (Lombardy) & $\begin{array}{l}\text { Electronic health records } \\
\text { extracted from three EDs. } \\
\text { The period } 8^{\text {th }} \text { March to 3rd } \\
\text { June } 2020 \text { was compared to } \\
\text { the equivalent calendar } \\
\text { period in } 2019 \text {. }\end{array}$ & $\begin{array}{l}\text { Three } \\
\text { categories of } \\
\text { self-harm - } \\
\text { suicide } \\
\text { attempt, self- } \\
\text { injuring, } \\
\text { drug } \\
\text { ingestion - } \\
\text { were } \\
\text { examined. }\end{array}$ & $\begin{array}{l}\text { Suicide attempts: } 1 \\
\text { in } 2019 \text { vs. } 3 \text { in } 2020 \\
\text { Self-injury: } 21 \text { in } \\
2019 \text { vs. } 14 \text { in } 2020 \\
\text { Drug ingestion: } 54 \text { in } \\
2019 \text { vs. } 49 \text { in } 2020 .\end{array}$ & $\begin{array}{l}\text { No statistical tests for } \\
\text { absolute differences } \\
\text { were reported. } \\
\text { No details about how } \\
\text { the three self-harm } \\
\text { categories were } \\
\text { classified was } \\
\text { provided. } \\
\text { Low event counts. }\end{array}$ & Low \\
\hline $\begin{array}{l}\text { 7. Gonçal } \\
\text { ves- } \\
\text { Pinho } \\
\text { et al., } \\
2020{ }^{46}\end{array}$ & $\begin{array}{l}\text { Peer- } \\
\text { reviewed } \\
\text { article }\end{array}$ & $\begin{array}{l}\text { Portugal (North } \\
\text { Region) }\end{array}$ & $\begin{array}{l}\text { People attending a } \\
\text { Psychiatric ED in a tertiary } \\
\text { hospital in North Portugal. } \\
\text { Attendances between March } \\
19 \text { th and May } 2^{\text {nd }} 2020 \text { (the } \\
\text { COVID-19 lockdown period } \\
\text { in Portugal) were compared } \\
\text { with the same dates in } 2019 \text {. }\end{array}$ & $\begin{array}{l}\text { 'Suicide } \\
\text { and self- } \\
\text { inflicted } \\
\text { presentations } \\
\text { to psychiatric } \\
\text { ED. }\end{array}$ & $\begin{array}{l}\text { A significant } \\
\text { reduction was } \\
\text { identified in numbers } \\
\text { of presentations of } \\
\text { suicide and } \\
\text { intentional } \\
\text { self-inflicted injury } \\
\text { during the COVID-19 } \\
\text { lockdown period } \\
\text { compared to the } \\
\text { same period in } 2019 \text { : } \\
\mathrm{N}=36 \text { vs. } 81 \text {, a } 56 \% \\
\text { reduction. }\end{array}$ & $\begin{array}{l}\text { The number of } \\
\text { patients presenting } \\
\text { with 'suicide and } \\
\text { intentional } \\
\text { self-inflicted injury' } \\
\text { included in the study } \\
\text { was relatively small. } \\
\text { While the study } \\
\text { stated ICD-9 codes } \\
\text { were used to identify } \\
\text { diagnostic groups, } \\
\text { the definition of } \\
\text { 'suicide }\end{array}$ & Low \\
\hline
\end{tabular}




\begin{tabular}{|c|c|c|c|c|c|c|c|}
\hline Authors & $\begin{array}{l}\text { Report } \\
\text { type }\end{array}$ & $\begin{array}{l}\text { Country } \\
\text { (region) of } \\
\text { study setting }\end{array}$ & $\begin{array}{l}\text { Study design and data } \\
\text { used }\end{array}$ & Outcome & Findings & $\begin{array}{l}\text { Comments/limitatio } \\
\text { ns including } \\
\text { considerations } \\
\text { from JBI checklist }\end{array}$ & $\begin{array}{l}\text { Quality } \\
\text { rating of } \\
\text { evidence } \\
\text { relating } \\
\text { specifically } \\
\text { to self- } \\
\text { harm }^{1}\end{array}$ \\
\hline & & & & & & $\begin{array}{l}\text { and self-inflicted } \\
\text { presentation' was not } \\
\text { provided. } \\
\text { Statistical tests were } \\
\text { not presented for } \\
\text { differences in. } \\
\text { numbers of visits } \\
\text { between the two time } \\
\text { periods. }\end{array}$ & \\
\hline $\begin{array}{l}\text { 8. Harmo } \\
\text { n, Fliss } \\
\text { et al. } \\
2021{ }^{47}\end{array}$ & $\begin{array}{l}\text { Peer- } \\
\text { reviewed } \\
\text { article }\end{array}$ & $\begin{array}{l}\text { USA (North } \\
\text { Carolina) }\end{array}$ & $\begin{array}{l}\text { State-wide hospital } \\
\text { surveillance system of ED } \\
\text { presentations from January } \\
\text { to mid- November in } 2019 \\
\text { and in } 2020 \text {. Data were } \\
\text { coded using ICD-10 codes } \\
\text { and Centers for Disease } \\
\text { Control and Prevention } \\
\text { (CDC) keywords. Quarterly } \\
\text { counts of ED presentations } \\
\text { for self-harm. Quarter } 2 \text { (1 } 1^{\text {st }} \\
\left.\text { April to } 30^{\text {th }} \text { June } 2020\right) \text { was } \\
\text { identified as the period } \\
\text { acutely affected by COVID- } \\
19 .\end{array}$ & $\begin{array}{l}\text { ED } \\
\text { presentation } \\
\text { for self-harm }\end{array}$ & $\begin{array}{l}\text { A } 26 \% \text { reduction in } \\
\text { presentations for } \\
\text { self-harm ( } 3167 \text { in } \\
2019 \text { vs. } 2352 \text { in } \\
2020 \text { ) was observed. } \\
\text { In the subsequent } \\
\text { quarters of } 2020 \text {, } \\
\text { numbers of self-harm } \\
\text { presentations almost } \\
\text { reached } 2019 \text { levels. }\end{array}$ & $\begin{array}{l}\text { Large, state-wide } \\
\text { study based on } \\
\text { existing data } \\
\text { collection systems. } \\
\text { No information on } \\
\text { missing data was } \\
\text { provided. }\end{array}$ & Moderate \\
\hline $\begin{array}{l}\text { 9. Hawton } \\
\text {, Casey } \\
\text { et al. } \\
2021{ }^{48}\end{array}$ & $\begin{array}{l}\text { Peer- } \\
\text { reviewed } \\
\text { article }\end{array}$ & $\begin{array}{l}\text { England (Oxford } \\
\text { and Derby) }\end{array}$ & $\begin{array}{l}\text { Data were collected from } \\
\text { EDs of two general hospitals. } \\
\text { In one hospital data were } \\
\text { extracted from monitoring } \\
\text { forms completed by clinicians }\end{array}$ & $\begin{array}{l}\text { Self-harm } \\
\text { presentations } \\
\text { to ED }\end{array}$ & $\begin{array}{l}\text { There was a } 37 \% \\
\text { reduction in mean } \\
\text { number of weekly } \\
\text { self-harm } \\
\text { presentations during }\end{array}$ & $\begin{array}{l}\text { A broad definition of } \\
\text { self-harm was } \\
\text { included. Only } \\
\text { hospital } \\
\text { presentations }\end{array}$ & Moderate \\
\hline
\end{tabular}




\begin{tabular}{|c|c|c|c|c|c|c|c|}
\hline Authors & $\begin{array}{l}\text { Report } \\
\text { type }\end{array}$ & $\begin{array}{l}\text { Country } \\
\text { (region) of } \\
\text { study setting }\end{array}$ & $\begin{array}{l}\text { Study design and data } \\
\text { used }\end{array}$ & Outcome & Findings & $\begin{array}{l}\text { Comments/limitatio } \\
\text { ns including } \\
\text { considerations } \\
\text { from JBI checklist }\end{array}$ & $\begin{array}{l}\text { Quality } \\
\text { rating of } \\
\text { evidence } \\
\text { relating } \\
\text { specifically } \\
\text { to self- } \\
\text { harm }^{1}\end{array}$ \\
\hline & & & $\begin{array}{l}\text { treating patients presenting } \\
\text { with self-harm and, in the } \\
\text { other hospital they were } \\
\text { extracted from electronic } \\
\text { health records. Mean number } \\
\text { of weekly presentations } \\
\text { during the lockdown period } \\
\left(23^{\text {rd }} \text { March to } 14^{\text {th }} \text { June }\right. \\
2020) \text { compared to the } \\
\text { equivalent calendar period in } \\
2019 \text { as well as a pre- } \\
\text { lockdown period }\left(6^{\text {th }} \text { January }\right. \\
\left.\text { to } 22^{\text {nd }} \text { March } 2020\right) \text {. }\end{array}$ & & $\begin{array}{l}\text { the lockdown period } \\
\text { compared to the } \\
\text { equivalent calendar } \\
\text { period in } 2019 .\end{array}$ & $\begin{array}{l}\text { followed by an } \\
\text { assessment were } \\
\text { included, rather than } \\
\text { all presentations. } \\
\text { There was a larger } \\
\text { reduction for } \\
\text { presentations } \\
\text { involving self- } \\
\text { poisoning. }\end{array}$ & \\
\hline $\begin{array}{l}\text { 10. Jollant, } \\
\text { Rousso } \\
t \text { et al. } \\
2021^{8}\end{array}$ & $\begin{array}{l}\text { Peer- } \\
\text { reviewed } \\
\text { article }\end{array}$ & $\begin{array}{l}\text { France } \\
\text { (nationwide) }\end{array}$ & $\begin{array}{l}\text { Data were from a national } \\
\text { database of patients } \\
\text { admitted to hospitals. All } \\
\text { hospital stays for self-harm } \\
\text { (based on ICD codes) were } \\
\text { included. Monthly numbers of } \\
\text { hospital stays for self-harm, } \\
\text { from January to August } 2020 \\
\text { compared to the same } \\
\text { months in } 2019,2018 \text { and } \\
2017 \text {. }\end{array}$ & $\begin{array}{l}\text { Hospitalisatio } \\
\mathrm{n} \text { for self- } \\
\text { harm. }\end{array}$ & $\begin{array}{l}\text { An overall decrease } \\
\text { of } 8.5 \% \text { was found in } \\
\text { the months of } \\
\text { January to August } \\
2020 \text { compared to } \\
2019 \text {, with a } 21.1 \% \\
\text { reduction in April } \\
2020 \text { compared to } \\
2019 \text {. } \\
\text { Increase in } \\
\text { hospitalisations } \\
\text { found among people } \\
\text { aged } 75 \text { years and } \\
\text { over. } \\
\text { Separate analysis } \\
\text { was conducted on }\end{array}$ & $\begin{array}{l}\text { Self-harm } \\
\text { presentations not } \\
\text { resulting in } \\
\text { hospitalisation were } \\
\text { not included. } \\
\\
\text { Statistical tests were } \\
\text { presented for } \\
\text { monthly differences. }\end{array}$ & Moderate \\
\hline
\end{tabular}




\begin{tabular}{|c|c|c|c|c|c|c|c|}
\hline Authors & $\begin{array}{l}\text { Report } \\
\text { type }\end{array}$ & $\begin{array}{l}\text { Country } \\
\text { (region) of } \\
\text { study setting }\end{array}$ & $\begin{array}{l}\text { Study design and data } \\
\text { used }\end{array}$ & Outcome & Findings & $\begin{array}{l}\text { Comments/limitatio } \\
\text { ns including } \\
\text { considerations } \\
\text { from JBI checklist }\end{array}$ & $\begin{array}{l}\text { Quality } \\
\text { rating of } \\
\text { evidence } \\
\text { relating } \\
\text { specifically } \\
\text { to self- } \\
\text { harm }^{1}\end{array}$ \\
\hline & & & & & $\begin{array}{l}\text { more serious } \\
\text { episodes (those } \\
\text { leading to ICU } \\
\text { admission and those } \\
\text { using violent } \\
\text { methods). Both } \\
\text { increased in } \\
\text { frequency during the } \\
2020 \text { period. }\end{array}$ & & \\
\hline $\begin{array}{l}\text { 11. Mansfi } \\
\text { eld, } \\
\text { Mathur } \\
\text { et al. } \\
2021)^{6}\end{array}$ & $\begin{array}{l}\text { Peer- } \\
\text { reviewed } \\
\text { article }\end{array}$ & $\begin{array}{l}\text { England and } \\
\text { Northern Ireland }\end{array}$ & $\begin{array}{l}\text { General practices } \\
\text { contributing data to the } \\
\text { Clinical Practice Research } \\
\text { Datalink, including around } 10 \\
\text { million individuals. Weekly } \\
\text { primary care contacts among } \\
\text { patients aged } 11 \text { years and } \\
\text { over in a pre-COVID-19 } \\
\text { period ( } 1^{\text {st }} \text { January } 2017 \text { to } \\
\left.7^{\text {th }} \text { March } 2020\right) \text { were } \\
\text { compared to the period with } \\
\text { COVID-19 restrictions }\left(28^{\text {th }}\right. \\
\left.\text { March to } 18^{\text {th }} \text { July } 2020\right) .\end{array}$ & $\begin{array}{l}\text { Primary care- } \\
\text { recorded } \\
\text { self-harm }\end{array}$ & $\begin{array}{l}\text { Reductions in } \\
\text { primary care } \\
\text { contacts for self- } \\
\text { harm during the } \\
\text { COVID-19 period } \\
\text { were observed: odds } \\
\text { ratio } 0.56(\mathrm{Cl} 0.54- \\
0.58) \text {. }\end{array}$ & $\begin{array}{l}\text { This was a large } \\
\text { study, using a broad } \\
\text { definition of self- } \\
\text { harm. } \\
\text { While the study } \\
\text { states it is based in } \\
\text { the UK, only data } \\
\text { from English and } \\
\text { Northern Irish } \\
\text { practices were } \\
\text { included. It is not } \\
\text { known how many of } \\
\text { the primary care } \\
\text { recorded self-harm } \\
\text { episodes led to } \\
\text { hospital } \\
\text { presentations. }\end{array}$ & $\begin{array}{l}\text { High/moder } \\
\text { ate }\end{array}$ \\
\hline $\begin{array}{l}\text { 12. Mclntyr } \\
\text { e et al. } \\
2021^{75}\end{array}$ & $\begin{array}{l}\text { Peer- } \\
\text { reviewed } \\
\text { article }\end{array}$ & Ireland (Galway) & $\begin{array}{l}\text { The liaison psychiatry team } \\
\text { hospital database, which } \\
\text { includes self-harm referrals }\end{array}$ & $\begin{array}{l}\text { Numbers of } \\
\text { referrals to } \\
\text { liaison }\end{array}$ & $\begin{array}{l}\text { In the period March- } \\
\text { May } 2020, \text { there } \\
\text { were } 119 \text { referrals, }\end{array}$ & $\begin{array}{l}\text { Incidence based on } \\
\text { referrals to liaison } \\
\text { psychiatry, which is }\end{array}$ & Moderate \\
\hline
\end{tabular}




\begin{tabular}{|c|c|c|c|c|c|c|c|}
\hline Authors & $\begin{array}{l}\text { Report } \\
\text { type }\end{array}$ & $\begin{array}{l}\text { Country } \\
\text { (region) of } \\
\text { study setting }\end{array}$ & $\begin{array}{l}\text { Study design and data } \\
\text { used }\end{array}$ & Outcome & Findings & $\begin{array}{l}\text { Comments/limitatio } \\
\text { ns including } \\
\text { considerations } \\
\text { from JBI checklist }\end{array}$ & $\begin{array}{l}\text { Quality } \\
\text { rating of } \\
\text { evidence } \\
\text { relating } \\
\text { specifically } \\
\text { to self- } \\
\text { harm }^{1}\end{array}$ \\
\hline & & & $\begin{array}{l}\text { from ED, medical and } \\
\text { surgical wards and the } \\
\text { critical care unit at one } \\
\text { hospital. A COVID-19 study } \\
\text { period of } 1 \text { March } 2020-31 \\
\text { May } 2020 \text { was compared } \\
\text { with the same period in } \\
2017-2019 \text {. }\end{array}$ & $\begin{array}{l}\text { psychiatry } \\
\text { from ED, } \\
\text { medical and } \\
\text { surgical ward } \\
\text { and critical } \\
\text { care unit } \\
\text { following } \\
\text { self-harm. }\end{array}$ & $\begin{array}{l}\text { significantly lower } \\
\text { than in the same } \\
\text { period in } 2019(130) \text {, } \\
\text { an } 8.5 \% \text { reduction. } \\
\text { The reduction was } \\
\text { greatest in the } \\
\text { March-April period (- } \\
35 \%) \text {. } \\
\text { An increase in } \\
\text { lethality of } \\
\text { presentations was } \\
\text { observed. }\end{array}$ & $\begin{array}{l}\text { likely to under- } \\
\text { estimate total } \\
\text { hospital-presenting } \\
\text { cases. } \\
\text { Liaison psychiatry } \\
\text { referral pathways } \\
\text { may have changed } \\
\text { as a result of COVID- } \\
\text { 19. } \\
\text { Broad definition of } \\
\text { self-harm provided, } \\
\text { though details on } \\
\text { how records } \\
\text { involving self-harm } \\
\text { were selected was } \\
\text { not provided. } \\
\text { Significance testing } \\
\text { was only presented } \\
\text { for differences in } \\
\text { proportions of } \\
\text { presentation types. }\end{array}$ & \\
\hline $\begin{array}{l}\text { 13. Mourou } \\
\text { vaye, } \\
\text { Bottem } \\
\text { anne et } \\
\text { al. } \\
2020^{28}\end{array}$ & $\begin{array}{l}\text { Peer- } \\
\text { reviewed } \\
\text { article }\end{array}$ & France (Paris) & $\begin{array}{l}\text { Data pertained to one } \\
\text { paediatric hospital in Paris. } \\
\text { This was a retrospective } \\
\text { observational study, with } \\
\text { outcome data obtained from } \\
\text { discharge codes (ICD codes } \\
\text { applied unspecified). The }\end{array}$ & $\begin{array}{l}\text { ED and } \\
\text { hospital } \\
\text { admissions } \\
\text { for suicidal } \\
\text { behaviour }\end{array}$ & $\begin{array}{l}\text { A } 50 \% \text { reduction in } \\
\text { was observed during } \\
\text { the lockdown period. } \\
\text { There was no } \\
\text { difference in } \\
\text { observed } \\
\text { characteristics of }\end{array}$ & $\begin{array}{l}\text { The specific suicidal } \\
\text { behaviours included } \\
\text { in the outcome } \\
\text { measure were not } \\
\text { specified, though } \\
\text { ICD-10 codes were } \\
\text { used. }\end{array}$ & Moderate \\
\hline
\end{tabular}




\begin{tabular}{|c|c|c|c|c|c|c|c|}
\hline Authors & $\begin{array}{l}\text { Report } \\
\text { type }\end{array}$ & $\begin{array}{l}\text { Country } \\
\text { (region) of } \\
\text { study setting }\end{array}$ & $\begin{array}{l}\text { Study design and data } \\
\text { used }\end{array}$ & Outcome & Findings & $\begin{array}{l}\text { Comments/limitatio } \\
\text { ns including } \\
\text { considerations } \\
\text { from JBI checklist }\end{array}$ & $\begin{array}{l}\text { Quality } \\
\text { rating of } \\
\text { evidence } \\
\text { relating } \\
\text { specifically } \\
\text { to self- } \\
\text { harm }^{1}\end{array}$ \\
\hline & & & $\begin{array}{l}\text { study period was between } 1^{\text {st }} \\
\text { January } 2018 \text { and } 1^{\text {st }} \text { June } \\
2020 \text {. The French COVID-19 } \\
\text { lockdown period }\left(16^{\text {th }} \text { March }\right. \\
\left.2020 \text { to } 10^{\text {th }} \text { May } 2020\right) \text { was } \\
\text { compared to the study period } \\
\text { before and after the } \\
\text { lockdown. Numbers of ED } \\
\text { and hospital admissions for } \\
\text { suicidal behaviour among } \\
\text { children aged } 7-17 \text { years } \\
\text { were compared. }\end{array}$ & & $\begin{array}{l}\text { patients (including } \\
\text { proportion admitted } \\
\text { to intensive care } \\
\text { units) between the } \\
\text { two periods. } \\
\text { The incidence of } \\
\text { admissions for } \\
\text { suicidal behaviour } \\
\text { was also lower } \\
\text { during summer } \\
\text { breaks. }\end{array}$ & $\begin{array}{l}\text { The overall number } \\
\text { of admissions during } \\
\text { the two time periods } \\
\text { was stated ( } 234 \\
\text { between } 1 \text { January } \\
2018 \text { and } 1 \text { June } \\
2020 \text { ), but the } \\
\text { number of } \\
\text { admissions during } \\
\text { the lockdown period } \\
\text { was not. Confidence } \\
\text { intervals were } \\
\text { relatively wide. }\end{array}$ & \\
\hline $\begin{array}{l}\text { 14. Nuzum, } \\
2020^{76}\end{array}$ & Preprint & $\begin{array}{l}\text { UK ( } 4 \text { boroughs } \\
\text { in South } \\
\text { London) }\end{array}$ & $\begin{array}{l}\text { Researchers extracted data } \\
\text { from ED and 'place of safety' } \\
\text { electronic health records. } \\
\text { Three periods in } 2020 \text { were } \\
\text { compared: before }\left(3^{\text {rd }}\right. \\
\text { February), during ( } 16^{\text {th }} \text { March } \\
\text { to } 10^{\text {th }} \text { May) and after } \\
\text { lockdown }\left(11^{\text {th }} \text { May to } 28^{\text {th }}\right. \\
\text { June). }\end{array}$ & $\begin{array}{l}\text { The outcome } \\
\text { measures } \\
\text { were self- } \\
\text { harm and } \\
\text { categories of } \\
\text { self-harm } \\
\text { including } \\
\text { self- } \\
\text { poisoning, } \\
\text { self-injury } \\
\text { and } \\
\text { combined/oth } \\
\text { er self-harm. }\end{array}$ & $\begin{array}{l}\text { Mean weekly } \\
\text { presentations of self- } \\
\text { harm were } 34 \% \\
\text { lower during } \\
\text { lockdown compared } \\
\text { to the pre-lockdown } \\
\text { period and 37\% } \\
\text { higher in the post- } \\
\text { lockdown period } \\
\text { compared to the } \\
\text { lockdown period. } \\
\text { Reductions in the } \\
\text { lockdown period } \\
\text { compared to the pre- } \\
\text { lockdown were } \\
\text { highest for }\end{array}$ & $\begin{array}{l}\text { There were small } \\
\text { sample sizes when } \\
\text { comparing self-harm } \\
\text { attendance } \\
\text { frequencies. The } \\
\text { level of agreement } \\
\text { between researchers } \\
\text { coding self-harm } \\
\text { from the electronic } \\
\text { health records was } \\
\text { high. Only episodes } \\
\text { assessed by the } \\
\text { mental health liaison } \\
\text { team were included. } \\
\text { However, it is not } \\
\text { clear if the pandemic } \\
\text { affected likelihood of }\end{array}$ & Moderate \\
\hline
\end{tabular}




\begin{tabular}{|c|c|c|c|c|c|c|c|}
\hline Authors & $\begin{array}{l}\text { Report } \\
\text { type }\end{array}$ & $\begin{array}{l}\text { Country } \\
\text { (region) of } \\
\text { study setting }\end{array}$ & $\begin{array}{l}\text { Study design and data } \\
\text { used }\end{array}$ & Outcome & Findings & $\begin{array}{l}\text { Comments/limitatio } \\
\text { ns including } \\
\text { considerations } \\
\text { from JBI checklist }\end{array}$ & $\begin{array}{l}\text { Quality } \\
\text { rating of } \\
\text { evidence } \\
\text { relating } \\
\text { specifically } \\
\text { to self- } \\
\text { harm }^{1}\end{array}$ \\
\hline & & & & & $\begin{array}{l}\text { presentations for } \\
\text { self-injury, while } \\
\text { increases in the post- } \\
\text { lockdown period } \\
\text { compared to } \\
\text { lockdown were } \\
\text { highest in this group. }\end{array}$ & assessment. & \\
\hline $\begin{array}{l}\text { 15. Ontiver } \\
\text { os, } \\
\text { Levine } \\
\text { et al. } \\
2021{ }^{51}\end{array}$ & $\begin{array}{l}\text { Peer- } \\
\text { reviewed } \\
\text { article }\end{array}$ & USA (California) & $\begin{array}{l}\text { Retrospective review of data } \\
\text { from the California Poison } \\
\text { Control System. Monthly } \\
\text { numbers of calls involving } \\
\text { suicide attempts made to the } \\
\text { California Poison Control } \\
\text { System, from health services } \\
\text { and residents. A 'pre-COVID } \\
\text { era' (March, April, and May } \\
2018 \text { and 2019) was } \\
\text { compared to the 'COVID } \\
\text { era', defined as March, April, } \\
\text { and May 2020. }\end{array}$ & $\begin{array}{l}\text { Self- } \\
\text { poisoning }\end{array}$ & $\begin{array}{l}\text { The number of calls } \\
\text { involving suspected } \\
\text { suicide attempts was } \\
\text { lower during the } \\
\text { COVID era, } \\
\text { compared with the } \\
\text { pre-COVID era. } \\
\text { Reductions in all age } \\
\text { groups were } \\
\text { observed except for } \\
70+\text { years }\end{array}$ & $\begin{array}{l}\text { Only self-harm } \\
\text { involving self- } \\
\text { poisoning was } \\
\text { included. The } \\
\text { method for } \\
\text { determining which } \\
\text { calls related to } \\
\text { poisonings that were } \\
\text { 'suspected suicide } \\
\text { attempts' was not } \\
\text { described. }\end{array}$ & Low \\
\hline $\begin{array}{l}\text { 16. Pignon } \\
\text { et al. } \\
2020\end{array}$ & Letter & France (Paris) & $\begin{array}{l}\text { Data on emergency } \\
\text { psychiatric consultations } \\
\text { from } \\
\text { three psychiatric emergency } \\
\text { centres. Numbers during the } \\
\text { first four weeks of lockdown, } \\
\text { from March } 17^{\text {th }} 2020 \text { were } \\
\text { compared to the } \\
\text { corresponding weeks in } \\
2019 \text {. }\end{array}$ & $\begin{array}{l}\text { Suicide } \\
\text { attempts }\end{array}$ & $\begin{array}{l}\text { During the four first } \\
\text { weeks of lockdown, } \\
\text { consultations for } \\
\text { suicide attempts } \\
\text { reduced to } 32 \text { from } \\
75 \text { in the same } \\
\text { period in } 2019 \text {, a } \\
57 \% \text { reduction. }\end{array}$ & $\begin{array}{l}\text { This was a letter so } \\
\text { was relatively brief } \\
\text { with very little } \\
\text { information on } \\
\text { methods of data } \\
\text { extraction, inclusion } \\
\text { criteria, coding and } \\
\text { pooing of data from } \\
\text { the three centres. }\end{array}$ & Low \\
\hline
\end{tabular}




\begin{tabular}{|c|c|c|c|c|c|c|c|}
\hline Authors & $\begin{array}{l}\text { Report } \\
\text { type }\end{array}$ & $\begin{array}{l}\text { Country } \\
\text { (region) of } \\
\text { study setting }\end{array}$ & $\begin{array}{l}\text { Study design and data } \\
\text { used }\end{array}$ & Outcome & Findings & $\begin{array}{l}\text { Comments/limitatio } \\
\text { ns including } \\
\text { considerations } \\
\text { from JBI checklist }\end{array}$ & $\begin{array}{l}\text { Quality } \\
\text { rating of } \\
\text { evidence } \\
\text { relating } \\
\text { specifically } \\
\text { to self- } \\
\text { harm }^{1}\end{array}$ \\
\hline & & & & & & $\begin{array}{l}\text { Significance testing } \\
\text { was only presented } \\
\text { for differences in } \\
\text { proportions of } \\
\text { presentation types. }\end{array}$ & \\
\hline $\begin{array}{l}\text { 17. Steeg, } \\
\text { Bojanić } \\
\text { et al. } \\
2021{ }^{19}\end{array}$ & $\begin{array}{l}\text { Peer- } \\
\text { reviewed } \\
\text { article }\end{array}$ & $\begin{array}{l}\text { England } \\
\text { (Greater } \\
\text { Manchester) }\end{array}$ & $\begin{array}{l}\text { An integrated electronic } \\
\text { health record database } \\
\text { covering the whole GP- } \\
\text { registered population of a } \\
\text { large UK conurbation was } \\
\text { utilised to examine } \\
\text { frequencies of primary care- } \\
\text { recorded self-harm episodes } \\
\text { between } 1^{\text {st }} \text { January } 2019 \\
\text { and } 31^{\text {st }} \text { May } 2021 . \\
\text { Frequency of self-harm } \\
\text { episodes recorded in } \\
\text { patients' primary care } \\
\text { electronic health records } \\
\text { were examined. }\end{array}$ & $\begin{array}{l}\text { Primary care- } \\
\text { recorded } \\
\text { self-harm }\end{array}$ & $\begin{array}{l}\text { Frequency ratios of } \\
\text { incident and all } \\
\text { episodes of self- } \\
\text { harm were } 0.59 \text { and } \\
0.69 \text { respectively in } \\
\text { April } 2020 \text { compared } \\
\text { to February } 2020 \text {. } \\
\text { Between August } \\
2020 \text { and May } 2021 \\
\text { frequency ratios } \\
\text { were } 0.92 \text { for } \\
\text { incident } \\
\text { episodes and } 0.86 \\
\text { for all episodes } \\
\text { compared to the } \\
\text { same months in } \\
2019 \text {. }\end{array}$ & $\begin{array}{l}\text { Some of the primary } \\
\text { care-recorded } \\
\text { episodes are likely to } \\
\text { have been hospital } \\
\text { presentations. } \\
\text { The self-harm } \\
\text { outcome was based } \\
\text { on a broad definition } \\
\text { that included } \\
\text { episodes of varying } \\
\text { suicidal intent. }\end{array}$ & $\begin{array}{l}\text { High/moder } \\
\text { ate }\end{array}$ \\
\hline $\begin{array}{l}\text { 18. Walker } \\
\text { et al., } \\
2020{ }^{77}\end{array}$ & $\begin{array}{l}\text { Peer- } \\
\text { reviewed } \\
\text { article }\end{array}$ & USA (4 states) & $\begin{array}{l}\text { Data from } 18 \text { EDs in four } \\
\text { states (Minnesota, Florida, } \\
\text { Arizona and Wisconsin) from } \\
\text { electronic health records in } \\
\text { an integrated health system. } \\
\text { The pandemic period ( } 17\end{array}$ & $\begin{array}{l}\text { Numbers of } \\
\text { presentations } \\
\text { with a } \\
\text { diagnosis of } \\
\text { suicide } \\
\text { attempt }\end{array}$ & $\begin{array}{l}\text { Total ED } \\
\text { attendances with } \\
\text { 'suicide' diagnosis } \\
\text { were } 36 \text { during the } \\
\text { pandemic study } \\
\text { period compared to } \\
59 \text { in the equivalent }\end{array}$ & $\begin{array}{l}\text { Multi-site study using } \\
\text { data from an } \\
\text { integrated health } \\
\text { system. } \\
\text { Not clear what the } \\
\text { diagnosis 'suicide' }\end{array}$ & Low \\
\hline
\end{tabular}




\begin{tabular}{|c|c|c|c|c|c|c|c|}
\hline Authors & $\begin{array}{l}\text { Report } \\
\text { type }\end{array}$ & $\begin{array}{l}\text { Country } \\
\text { (region) of } \\
\text { study setting }\end{array}$ & $\begin{array}{l}\text { Study design and data } \\
\text { used }\end{array}$ & Outcome & Findings & $\begin{array}{l}\text { Comments/limitatio } \\
\text { ns including } \\
\text { considerations } \\
\text { from JBI checklist }\end{array}$ & $\begin{array}{l}\text { Quality } \\
\text { rating of } \\
\text { evidence } \\
\text { relating } \\
\text { specifically } \\
\text { to self- }^{\text {harm }}{ }^{1}\end{array}$ \\
\hline & & & $\begin{array}{l}\text { March - } 21 \text { April 2020) was } \\
\text { compared to the same period } \\
\text { in } 2019 \text { as well as a pre- } \\
\text { pandemic period in } 2020 \text { ( } 9 \\
\text { Feb to } 16 \text { - March 2020). }\end{array}$ & & $\begin{array}{l}2019 \text { period, a } \\
\text { reduction of } 39 \% \text {. }\end{array}$ & $\begin{array}{l}\text { included. } \\
\text { The statistical tests } \\
\text { compared suicide } \\
\text { attempts as a } \\
\text { proportion of total } \\
\text { attendances, rather } \\
\text { than changes in } \\
\text { absolute numbers. }\end{array}$ & \\
\hline $\begin{array}{l}\text { 19. Yard, } \\
\text { Radhak } \\
\text { rishnan } \\
\text { et al. } \\
2021^{18}\end{array}$ & $\begin{array}{l}\text { Report } \\
\text { (National } \\
\text { Center for } \\
\text { Injury } \\
\text { Preventio } \\
\text { n and } \\
\text { Control) }\end{array}$ & $\begin{array}{l}\text { USA (49 states } \\
\text { - all except } \\
\text { Hawaii) }\end{array}$ & $\begin{array}{l}\text { Study included approximately } \\
71 \% \text { of the US's EDs in } 49 \\
\text { states. The system is an } \\
\text { established programme } \\
\text { collecting data from ED } \\
\text { electronic health records. ED } \\
\text { presentations for suspected } \\
\text { suicide attempts among } \\
\text { people aged } 12 \text { to } 25 \text { years } \\
\text { up to March } 2021 \text {. }\end{array}$ & $\begin{array}{l}\text { ED } \\
\text { presentation } \\
\text { for suicide } \\
\text { attempt }\end{array}$ & $\begin{array}{l}\text { The average weekly } \\
\text { number of ED visits } \\
\text { for suspected suicide } \\
\text { attempts fell by } 26 \% \\
\text { among ages } 12-17 \\
\text { and by } 17 \% \text { among } \\
\text { ages } 18-25 \text { years } \\
\text { during spring } 2020 \\
\text { compared with the } \\
2019 \text { reference } \\
\text { period. } \\
\text { During summer } 2020 \\
\text { through to winter } \\
2021 \text {, increases } \\
\text { compared to } \\
\text { equivalent weeks in } \\
2019 \text { were found for } \\
\text { girls aged } 12-17 \text {. } \\
\text { Among boys aged } \\
12-17 \text { and all adults }\end{array}$ & $\begin{array}{l}\text { One of the few } \\
\text { studies to examine } \\
\text { longer-term impacts. } \\
\text { Latest date of study } \\
\text { period was } 20^{\text {th }} \\
\text { March } 2021 . \\
\text { Only EDs that } \\
\text { consistently reported } \\
\text { data to the } \\
\text { surveillance } \\
\text { programme were } \\
\text { included to improve } \\
\text { data quality. } \\
\text { Outcome included } \\
\text { 'some non-suicidal } \\
\text { self-harm' } \\
\text { presentations. }\end{array}$ & $\begin{array}{l}\text { High/moder } \\
\text { ate }\end{array}$ \\
\hline
\end{tabular}




\begin{tabular}{|c|c|c|c|c|c|c|c|}
\hline Authors & $\begin{array}{l}\text { Report } \\
\text { type }\end{array}$ & $\begin{array}{l}\text { Country } \\
\text { (region) of } \\
\text { study setting }\end{array}$ & $\begin{array}{l}\text { Study design and data } \\
\text { used }\end{array}$ & Outcome & Findings & $\begin{array}{l}\text { Comments/limitatio } \\
\text { ns including } \\
\text { considerations } \\
\text { from JBI checklist }\end{array}$ & $\begin{array}{l}\text { Quality } \\
\text { rating of } \\
\text { evidence } \\
\text { relating } \\
\text { specifically } \\
\text { to self- } \\
\text { harm }^{1}\end{array}$ \\
\hline & & & & & $\begin{array}{l}\text { aged } 18-25 \text { years, } \\
\text { rates in summer } \\
2020 \text { through to } \\
\text { winter } 2021 \text { were in } \\
\text { line with those in } \\
2019 .\end{array}$ & & \\
\hline $\begin{array}{l}\text { 20. Bothar } \\
\text { a, } \\
\text { Raina } \\
\text { et al. } \\
2021) \\
54\end{array}$ & $\begin{array}{l}\text { Peer- } \\
\text { reviewed } \\
\text { article }\end{array}$ & $\begin{array}{l}\text { New Zealand } \\
\text { (Christchurch) }\end{array}$ & $\begin{array}{l}\text { Single hospital ED. Data } \\
\text { were extracted from routinely } \\
\text { collected electronic health } \\
\text { records using the SNOMED } \\
\text { CT classification } \\
\text { system. Two cohorts were } \\
\text { compared: before lockdown, } \\
15^{\text {th }} \text { February to } 18^{\text {th }} \text { March } \\
2020 \text {, and during the } 33 \text { days } \\
\text { of lockdown, } 26^{\text {th }} \text { March to } \\
28^{\text {th }} \text { April } 2020 \text {. Numbers of } \\
\text { self-harm presentations by } \\
\text { children aged under } 16 \text { were } \\
\text { examined, with 'self-harm' as } \\
\text { one of the diagnostic } \\
\text { subcategories. }\end{array}$ & $\begin{array}{l}\text { Numbers of } \\
\text { self-harm } \\
\text { presentations } \\
\text { by children } \\
\text { aged under } \\
16 .\end{array}$ & $\begin{array}{l}\text { There were six } \\
\text { presentations during } \\
\text { the lockdown period } \\
\text { and none in the } \\
\text { period before the } \\
\text { lockdown. }\end{array}$ & $\begin{array}{l}\text { The self-harm } \\
\text { episode frequencies } \\
\text { were very low. } \\
\text { Data prior to } 2020 \\
\text { were unavailable for } \\
\text { comparison. }\end{array}$ & Low \\
\hline $\begin{array}{l}\text { 21. Canzi, } \\
\text { De } \\
\text { Ponti et } \\
\text { al. } \\
2020{ }^{55}\end{array}$ & $\begin{array}{l}\text { Peer- } \\
\text { reviewed } \\
\text { article }\end{array}$ & Italy (Milan) & $\begin{array}{l}\text { A single maxillofacial trauma } \\
\text { ED. Characteristics of } \\
\text { included patients were added } \\
\text { to a specific database. } \\
\text { Admission with diagnosis of } \\
\text { 'major trauma' (defined as }\end{array}$ & $\begin{array}{l}\text { Self-harm } \\
\text { requiring } \\
\text { admission for } \\
\text { major trauma }\end{array}$ & $\begin{array}{l}\text { In } 2020,31 \text { episodes } \\
\text { of self-harm meeting } \\
\text { the study inclusion } \\
\text { criteria were } \\
\text { recorded, an } \\
\text { increase compared }\end{array}$ & $\begin{array}{l}\text { The outcome was } \\
\text { limited to self-harm } \\
\text { resulting in major } \\
\text { trauma. } \\
\text { The process for data }\end{array}$ & Low \\
\hline
\end{tabular}




\begin{tabular}{|c|c|c|c|c|c|c|c|}
\hline Authors & $\begin{array}{l}\text { Report } \\
\text { type }\end{array}$ & $\begin{array}{l}\text { Country } \\
\text { (region) of } \\
\text { study setting }\end{array}$ & $\begin{array}{l}\text { Study design and data } \\
\text { used }\end{array}$ & Outcome & Findings & $\begin{array}{l}\text { Comments/limitatio } \\
\text { ns including } \\
\text { considerations } \\
\text { from JBI checklist }\end{array}$ & $\begin{array}{l}\text { Quality } \\
\text { rating of } \\
\text { evidence } \\
\text { relating } \\
\text { specifically } \\
\text { to self- } \\
\text { harm }^{1}\end{array}$ \\
\hline & & & $\begin{array}{l}\text { trauma with potential or } \\
\text { ongoing life-threatening } \\
\text { injuries) or facial trauma. } \\
\text { Suicide attempt was included } \\
\text { as a category of this } \\
\text { outcome. The COVID-19 } \\
\text { lockdown period, } 8^{\text {th }} \text { March } \\
2020 \text { to } 8^{\text {th }} \text { May } 2020 \text {, was } \\
\text { compared to the equivalent } \\
\text { calendar year periods in } \\
2017 \text { to } 2019 \text {. }\end{array}$ & & $\begin{array}{l}\text { to } 2017,2018 \text { and } \\
2019 .\end{array}$ & $\begin{array}{l}\text { extraction from the } \\
\text { clinical records to the } \\
\text { database was not } \\
\text { described. } \\
\text { Numbers of self- } \\
\text { harm outcome } \\
\text { events were low. } \\
\text { The increase in } \\
\text { frequency of self- } \\
\text { harm admissions } \\
\text { leading to major } \\
\text { trauma may indicate } \\
\text { greater severity of } \\
\text { self-harm during the } \\
\text { COVID-19 period. }\end{array}$ & \\
\hline $\begin{array}{l}\text { 22. Gracia, } \\
\text { Pamias } \\
\text { et al. } \\
2021{ }^{56}\end{array}$ & Letter & $\begin{array}{l}\text { Spain } \\
\text { (Catalonia) }\end{array}$ & $\begin{array}{l}\text { Population-based registry of } \\
\text { presentations to health } \\
\text { services for suicide attempts } \\
\text { among adolescents aged } 12- \\
18 \text { years. The first } 12 \text { months } \\
\text { of the } \\
\text { COVID-19 pandemic (March } \\
2020 \text { to March } 2021 \text { ) were } \\
\text { compared to the previous } 12 \\
\text { months (March } 2019 \text { to } \\
\text { March 2020). }\end{array}$ & $\begin{array}{l}\text { Suicide } \\
\text { attempts } \\
\text { among } \\
\text { adolescents } \\
\text { aged 12-18 } \\
\text { years. }\end{array}$ & $\begin{array}{l}\text { During the COVID-19 } \\
\text { period, } 690 \text { suicide } \\
\text { attempts were } \\
\text { registered compared } \\
\text { to } 552 \text { in the } \\
\text { previous year. A } \\
\text { significant increase } \\
\text { in frequency was } \\
\text { observed among } \\
\text { girls only. }\end{array}$ & $\begin{array}{l}\text { Definition of suicide } \\
\text { attempt not provided. } \\
\text { Exact health services } \\
\text { utilised are not } \\
\text { detailed. } \\
\text { Methodological } \\
\text { details lacking } \\
\text { (publication is a letter } \\
\text { not a full article). }\end{array}$ & Low \\
\hline $\begin{array}{l}\text { 23. Habu, } \\
\text { Takao }\end{array}$ & $\begin{array}{l}\text { Peer- } \\
\text { reviewed }\end{array}$ & $\begin{array}{l}\text { Japan } \\
\text { (Okayama) }\end{array}$ & $\begin{array}{l}\text { Electronic health records } \\
\text { from emergency ambulance }\end{array}$ & $\begin{array}{l}\text { Ambulance } \\
\text { dispatches }\end{array}$ & $\begin{array}{l}\text { The number of } \\
\text { emergency }\end{array}$ & $\begin{array}{l}\text { No measure or } \\
\text { definition of suicide }\end{array}$ & Low \\
\hline
\end{tabular}




\begin{tabular}{|c|c|c|c|c|c|c|c|}
\hline Authors & $\begin{array}{l}\text { Report } \\
\text { type }\end{array}$ & $\begin{array}{l}\text { Country } \\
\text { (region) of } \\
\text { study setting }\end{array}$ & $\begin{array}{l}\text { Study design and data } \\
\text { used }\end{array}$ & Outcome & Findings & $\begin{array}{l}\text { Comments/limitatio } \\
\text { ns including } \\
\text { considerations } \\
\text { from JBI checklist }\end{array}$ & $\begin{array}{l}\text { Quality } \\
\text { rating of } \\
\text { evidence } \\
\text { relating } \\
\text { specifically } \\
\text { to self- } \\
\text { harm }^{1}\end{array}$ \\
\hline $\begin{array}{l}\text { et al. } \\
202157\end{array}$ & article & & $\begin{array}{l}\text { calls during March to August } \\
\text { in } 2018,2019 \text {, and } 2020 .\end{array}$ & $\begin{array}{l}\text { for suicide } \\
\text { attempts. }\end{array}$ & $\begin{array}{l}\text { dispatches } \\
\text { related to suicide } \\
\text { attempts increased in } \\
2020 \text { (183) } \\
\text { compared to } 2018 \\
(149) \text { and } 2019 \\
(135) . \\
\text { Increases were } \\
\text { greater among } \\
\text { women and persons } \\
\text { aged } 25-49 \text {. No } \\
\text { change for ages 15- } \\
24 \text { was observed. }\end{array}$ & $\begin{array}{l}\text { attempt was provided } \\
\text {-identified as } \\
\text { recorded by } \\
\text { ambulance crews } \\
\text { No statistical testing } \\
\text { was conducted. }\end{array}$ & \\
\hline $\begin{array}{l}\text { 24. Henry, } \\
\text { Parthib } \\
\text { an et } \\
\text { al. } \\
2021{ }^{58}\end{array}$ & $\begin{array}{l}\text { Peer- } \\
\text { reviewed } \\
\text { article }\end{array}$ & $\begin{array}{l}\text { England } \\
\text { (Birmingham) }\end{array}$ & $\begin{array}{l}\text { Data were extracted from } \\
\text { coded electronic } \\
\text { health records from one } \\
\text { hospital. Numbers and } \\
\text { proportions of self-harm } \\
\text { presentations during the } \\
\text { lockdown period ( } 23^{\text {rd }} \text { March } \\
2020 \text { to } 1^{\text {st }} \text { May 2020) and } \\
\text { compared } \\
\text { to the equivalent calendar } \\
\text { period in } 2019 .\end{array}$ & $\begin{array}{l}\text { Total ED } \\
\text { presentations } \\
\text { involving } \\
\text { self-harm. }\end{array}$ & $\begin{array}{l}\text { Increase in total } \\
\text { number of self-harm } \\
\text { presentations in the } \\
\text { COVID- } 19 \text { period } \\
\text { compared to } 2019 \\
\text { (113 vs. 103). } \\
\text { More cases, and a } \\
\text { larger proportion of } \\
\text { the total, required } \\
\text { hospital admission in } \\
\text { the } 2020 \text { period. }\end{array}$ & $\begin{array}{l}\text { The main focus of } \\
\text { the study was on } \\
\text { proportions of total } \\
\text { presentations that } \\
\text { involved self-harm. } \\
\text { Only data from } 2019 \\
\text { were included in the } \\
\text { pre-COVID-19 } \\
\text { comparison period. }\end{array}$ & Low \\
\hline $\begin{array}{l}\text { 25. Holland } \\
\text {, Jones } \\
\text { et al. } \\
2021^{22}\end{array}$ & $\begin{array}{l}\text { Peer- } \\
\text { reviewed } \\
\text { article }\end{array}$ & $\begin{array}{l}\text { US (48 states } \\
\text { plus } \\
\text { Washington, } \\
\text { DC) }\end{array}$ & $\begin{array}{l}\text { Electronic health records } \\
\text { from more than } 3,500 \text { EDs } \\
\text { contributing data to the US } \\
\text { National Syndromic }\end{array}$ & $\begin{array}{l}\text { ED visits for } \\
\text { suicide } \\
\text { attempts }\end{array}$ & $\begin{array}{l}\text { Median ED } \\
\text { presentation counts } \\
\text { were significantly } \\
\text { higher in weeks } 12 \text { to }\end{array}$ & $\begin{array}{l}\text { Did not include self- } \\
\text { harm not classified } \\
\text { as a suicide attempt. }\end{array}$ & Moderate \\
\hline
\end{tabular}




\begin{tabular}{|c|c|c|c|c|c|c|c|}
\hline Authors & $\begin{array}{l}\text { Report } \\
\text { type }\end{array}$ & $\begin{array}{l}\text { Country } \\
\text { (region) of } \\
\text { study setting }\end{array}$ & $\begin{array}{l}\text { Study design and data } \\
\text { used }\end{array}$ & Outcome & Findings & $\begin{array}{l}\text { Comments/limitatio } \\
\text { ns including } \\
\text { considerations } \\
\text { from JBI checklist }\end{array}$ & $\begin{array}{l}\text { Quality } \\
\text { rating of } \\
\text { evidence } \\
\text { relating } \\
\text { specifically } \\
\text { to self- } \\
\text { harm }^{1}\end{array}$ \\
\hline & & & $\begin{array}{l}\text { Surveillance Program, } \\
\text { capturing approximately } 70 \% \\
\text { of US ED visits. Weekly ED } \\
\text { visit counts for suicide } \\
\text { attempts by patients aged } \\
\text { over } 10 \text { years, identified } \\
\text { using ICD and SNOMED } \\
\text { diagnostic codes. Mean } \\
\text { weekly ED visit counts were } \\
\text { presented for weeks } 1 \text { to } 11 \\
\text { (before } \\
\text { the decrease in overall ED } \\
\text { visits) and weeks } 12 \text { to } 41 \\
\text { (after the decrease in overall } \\
\text { ED visits and including the } \\
\text { period during } \\
\text { which the national 'stay-at- } \\
\text { home' order was in place). }\end{array}$ & & $\begin{array}{l}41 \text { of } 2020 \text { than } 2019 \\
\text { for suicide attempts } \\
(\mathrm{n}=4940 \text { vs } 4656, \mathrm{P} \\
=.02)\end{array}$ & $\begin{array}{l}\text { Broad coverage of } \\
\text { the US population. }\end{array}$ & \\
\hline $\begin{array}{l}\text { 26. Karaka } \\
\text { si et al., } \\
2020^{13}\end{array}$ & Letter & $\begin{array}{l}\text { Greece } \\
\text { (Thessaloniki) }\end{array}$ & $\begin{array}{l}\text { Numbers of psychiatric } \\
\text { emergency presentations to } \\
\text { the psychiatric emergency } \\
\text { department of AHEPA } \\
\text { University General } \\
\text { Hospital of Thessaloniki. The } \\
\text { comparison periods } 1 \text { March } \\
\text { to } 15-\text { May } 2019 \text { and } 15 \\
\text { November } 2019 \text { to } 31 \\
\text { January } 2020 \text { were } \\
\text { compared to } 1 \\
\text { March to } 15 \text { May } 2020 \text {. (the } \\
\text { COVID-19 period). }\end{array}$ & $\begin{array}{l}\text { Suicide } \\
\text { attempts }\end{array}$ & $\begin{array}{l}\text { During the restrictive } \\
\text { measures in Greece } \\
\text { (March - May 2020), } \\
\text { the number of } \\
\text { suicide attempts was } \\
\text { higher in March - } \\
\text { May } 2020(n=7) \\
\text { compared to the } \\
\text { same period in } 2019 \\
\text { ( } n=5) \text { and Nov } 2019 \\
\text {-Jan } 2020(n=4)\end{array}$ & $\begin{array}{l}\text { Significance testing } \\
\text { was only presented } \\
\text { for differences in } \\
\text { proportions of } \\
\text { presentation types. } \\
\text { Small numbers. } \\
\text { Uncertain if peer- } \\
\text { reviewed. } \\
\text { Definition of suicide } \\
\text { attempt was not }\end{array}$ & Low \\
\hline
\end{tabular}




\begin{tabular}{|c|c|c|c|c|c|c|c|}
\hline Authors & $\begin{array}{l}\text { Report } \\
\text { type }\end{array}$ & $\begin{array}{l}\text { Country } \\
\text { (region) of } \\
\text { study setting }\end{array}$ & $\begin{array}{l}\text { Study design and data } \\
\text { used }\end{array}$ & Outcome & Findings & $\begin{array}{l}\text { Comments/limitatio } \\
\text { ns including } \\
\text { considerations } \\
\text { from JBI checklist }\end{array}$ & $\begin{array}{l}\text { Quality } \\
\text { rating of } \\
\text { evidence } \\
\text { relating } \\
\text { specifically } \\
\text { to self- } \\
\text { harm }^{1}\end{array}$ \\
\hline & & & & & & provided. & \\
\hline $\begin{array}{l}\text { 27. Moore, } \\
\text { Siriwar } \\
\text { dena et } \\
\text { al. } \\
2021^{59}\end{array}$ & $\begin{array}{l}\text { Peer- } \\
\text { reviewed } \\
\text { article }\end{array}$ & $\begin{array}{l}\text { England (East } \\
\text { Midlands region) }\end{array}$ & $\begin{array}{l}\text { Electronic health records of } \\
\text { ambulance paramedics } \\
\text { attending mental health } \\
\text { emergencies between } 23^{\text {rd }} \\
\text { March and } 31^{\text {st }} \text { July } 2020 \\
\text { compared to the equivalent } \\
\text { calendar period in } \\
2019 \text {. }\end{array}$ & $\begin{array}{l}\text { Emergency } \\
\text { calls for } \\
\text { 'suicide } \\
\text { attempt' and } \\
\text { 'intentional } \\
\text { drug } \\
\text { overdose'. }\end{array}$ & $\begin{array}{l}\text { The numbers of } \\
\text { suicide attempts } \\
\text { were } 1232 \text { in the } \\
\text { lockdown period vs. } \\
1339 \text { in the } \\
\text { equivalent period in } \\
2019 \text {. Intentional } \\
\text { drug overdoses were } \\
3079 \text { in } 2020 \text { vs. } \\
3227 \text { in } 2019 \text {. }\end{array}$ & $\begin{array}{l}\text { Categories of } \\
\text { 'suicide attempt' and } \\
\text { 'intentional drug } \\
\text { overdose' were } \\
\text { based on clinical } \\
\text { impressions. } \\
\text { No tests for statistical } \\
\text { significance of } \\
\text { differences in } \\
\text { numbers were } \\
\text { presented. }\end{array}$ & Low \\
\hline $\begin{array}{l}\text { 28. Nia, } \\
\text { Popp et } \\
\text { al. } \\
2021^{60}\end{array}$ & $\begin{array}{l}\text { Peer- } \\
\text { reviewed } \\
\text { article }\end{array}$ & Austria (Vienna) & $\begin{array}{l}\text { Data were from one trauma } \\
\text { centre registry. Numbers of } \\
\text { patient visits were compared } \\
\text { between } 15^{\text {th }} \text { March } 2020 \\
\text { and } 30^{\text {th }} \text { April } 2020 \\
\text { (lockdown) and the } \\
\text { equivalent calendar period in } \\
2019 \text { (baseline). }\end{array}$ & $\begin{array}{l}\text { Trauma } \\
\text { admission for } \\
\text { suicide } \\
\text { attempt. }\end{array}$ & $\begin{array}{l}\text { There was a } \\
\text { significant increase } \\
\text { in the frequency of } \\
\text { hospital admissions } \\
\text { due to attempted } \\
\text { suicide, though } \\
\text { numbers were very } \\
\text { small ( } 5 \text { in the } \\
\text { comparison period } \\
\text { vs. } 10 \text { in the } \\
\text { lockdown period). }\end{array}$ & $\begin{array}{l}\text { No definition of } \\
\text { 'suicide attempt' was } \\
\text { provided. No search } \\
\text { terms of clinical } \\
\text { codes were provided } \\
\text { for identifying these } \\
\text { presentations. }\end{array}$ & Low \\
\hline $\begin{array}{l}\text { 29. Olding } \\
\text { et al., } \\
20211^{14}\end{array}$ & $\begin{array}{l}\text { Peer- } \\
\text { reviewed } \\
\text { article }\end{array}$ & $\begin{array}{l}\text { England } \\
\text { (London) }\end{array}$ & $\begin{array}{l}\text { Data were from patient } \\
\text { records. Numbers of } \\
\text { presentations by trauma } \\
\text { patients with penetrating } \\
\text { injuries }\end{array}$ & $\begin{array}{l}\text { Self-inflicted } \\
\text { injuries } \\
\text { requiring } \\
\text { treatment for } \\
\text { penetrating }\end{array}$ & $\begin{array}{l}\text { The number of self- } \\
\text { harm episodes } \\
\text { increased from } n=1 \\
\text { in } 2018 \text { to } 5 \text { in } 2019 \\
\text { and } 8 \text { in } 2020 \text {. }\end{array}$ & $\begin{array}{l}\text { Number of self-harm } \\
\text { cases was too small } \\
\text { to draw any strong } \\
\text { conclusions. }\end{array}$ & Low \\
\hline
\end{tabular}




\begin{tabular}{|c|c|c|c|c|c|c|c|}
\hline Authors & $\begin{array}{l}\text { Report } \\
\text { type }\end{array}$ & $\begin{array}{l}\text { Country } \\
\text { (region) of } \\
\text { study setting }\end{array}$ & $\begin{array}{l}\text { Study design and data } \\
\text { used }\end{array}$ & Outcome & Findings & $\begin{array}{l}\text { Comments/limitatio } \\
\text { ns including } \\
\text { considerations } \\
\text { from JBI checklist }\end{array}$ & $\begin{array}{l}\text { Quality } \\
\text { rating of } \\
\text { evidence } \\
\text { relating } \\
\text { specifically } \\
\text { to self- } \\
\text { harm }^{1}\end{array}$ \\
\hline & & & $\begin{array}{l}\text { who were treated at one } \\
\text { hospital in London, } 23 \text { rd } \\
\text { March to 29th April } 2020 \\
\text { were compared to the same } \\
\text { period in } 2018 \text { and } \\
2019 \text {. }\end{array}$ & trauma. & & $\begin{array}{l}\text { Significance testing } \\
\text { was not conducted. } \\
\text { Very little information } \\
\text { on methods of data } \\
\text { extraction and coding } \\
\text { was provided. }\end{array}$ & \\
\hline $\begin{array}{l}\text { 30. Popp, } \\
\text { Smolle } \\
\text { et al. } \\
2021^{61}\end{array}$ & $\begin{array}{l}\text { Peer- } \\
\text { reviewed } \\
\text { article }\end{array}$ & Austria (Graz) & $\begin{array}{l}\text { Division of Plastic, Aesthetic } \\
\text { and Reconstructive Surgery } \\
\text { at Medical University Graz. } \\
\text { Retrospective study of } \\
\text { patient records. The number } \\
\text { of surgery cases during the } \\
\text { lockdown period plus two } \\
\text { weeks before lockdown ( } 16^{\text {th }} \\
\text { March } 2020 \text { to } 27^{\text {th }} \text { April } \\
2020) \text { were compared with } \\
\text { the equivalent calendar } \\
\text { periods in } 2019 \text {. The number } \\
\text { of 'self-inflicted injuries and } \\
\text { suicide attempts' was } \\
\text { examined as a subcategory. }\end{array}$ & $\begin{array}{l}\text { Self-harm } \\
\text { requiring } \\
\text { surgery }\end{array}$ & $\begin{array}{l}\text { The number of } \\
\text { procedures following } \\
\text { self-harm increased } \\
\text { significantly }(2019: 0 \text {, } \\
2020: 16 \text { cases, } p< \\
0.001) \text {. }\end{array}$ & $\begin{array}{l}\text { Numbers in both the } \\
\text { lockdown and } 2019 \\
\text { periods were low. } \\
\text { Only self-harm } \\
\text { requiring plastic, } \\
\text { aesthetic or } \\
\text { reconstructive } \\
\text { surgery was included } \\
\text { in the outcome } \\
\text { measure. }\end{array}$ & Moderate \\
\hline $\begin{array}{l}\text { 31. Rhodes } \\
\text { et al. } \\
2020^{15}\end{array}$ & $\begin{array}{l}\text { Peer- } \\
\text { reviewed } \\
\text { article }\end{array}$ & $\begin{array}{l}\text { USA (South } \\
\text { Carolina) }\end{array}$ & $\begin{array}{l}\text { Data were from a registry of } \\
\text { attendees at one Level } 1 \\
\text { trauma centre. Numbers of } \\
\text { admissions were compared } \\
\text { between the period including } \\
\text { the COVID-19 lockdown } \\
\text { (January } 1 \text { - May } 12020 \text { ) } \\
\text { and the January } 1 \text { - May } 1\end{array}$ & $\begin{array}{l}\text { Suicide } \\
\text { attempts } \\
\text { requiring } \\
\text { trauma } \\
\text { treatment }\end{array}$ & $\begin{array}{l}\text { There were } 11 \\
\text { admissions for } \\
\text { suicide attempt in the } \\
2020 \text { study period } \\
\text { compared to } 6 \text { in the } \\
2019 \text { comparison } \\
\text { period. }\end{array}$ & $\begin{array}{l}\text { Most of the } 2020 \\
\text { period studied (15 of } \\
\text { the } 18 \text { weeks) } \\
\text { preceded lockdown. } \\
\text { Small numbers. } \\
\text { The statistical tests }\end{array}$ & Low \\
\hline
\end{tabular}




\begin{tabular}{|c|c|c|c|c|c|c|c|}
\hline Authors & $\begin{array}{l}\text { Report } \\
\text { type }\end{array}$ & $\begin{array}{l}\text { Country } \\
\text { (region) of } \\
\text { study setting }\end{array}$ & $\begin{array}{l}\text { Study design and data } \\
\text { used }\end{array}$ & Outcome & Findings & $\begin{array}{l}\text { Comments/limitatio } \\
\text { ns including } \\
\text { considerations } \\
\text { from JBI checklist }\end{array}$ & $\begin{array}{l}\text { Quality } \\
\text { rating of } \\
\text { evidence } \\
\text { relating } \\
\text { specifically } \\
\text { to self- } \\
\text { harm }^{1}\end{array}$ \\
\hline & & & period in 2019. & & & $\begin{array}{l}\text { compared suicide } \\
\text { attempts as a } \\
\text { proportion of total } \\
\text { attendances, rather } \\
\text { than changes in } \\
\text { absolute numbers. }\end{array}$ & \\
\hline $\begin{array}{l}\text { 32. Bruns, } \\
\text { Willem } \\
\text { sen et } \\
\text { al. } \\
202162\end{array}$ & Preprint & $\begin{array}{l}\text { Germany } \\
\text { (multiple } \\
\text { regions) }\end{array}$ & $\begin{array}{l}\text { Multicentre study of } 37 \\
\text { paediatric intensive care } \\
\text { units (ICUs). Patients under } \\
18 \text { years of age who } \\
\text { presented with trauma or } \\
\text { injuries during the period of } \\
\text { the first German COVID-19 } \\
\text { lockdown ( } 16^{\text {th }} \text { March to } 31^{\text {st }} \\
\text { May) in the years } 2017 \text { to } \\
2020 \text {. Data were manually } \\
\text { entered into data collection } \\
\text { forms from discharge } \\
\text { summaries. }\end{array}$ & $\begin{array}{l}\text { ICU } \\
\text { admission } \\
\text { following } \\
\text { suicide } \\
\text { attempt. }\end{array}$ & $\begin{array}{l}\text { No statistically } \\
\text { significant difference } \\
\text { in standardised } \\
\text { morbidity ratios } \\
\text { between the } \\
\text { lockdown period and } \\
\text { the } 2017-2019 \\
\text { reference period } \\
\text { were observed. }\end{array}$ & $\begin{array}{l}\text { Numbers were low: } \\
29 \text { in the lockdown } \\
\text { period. } \\
\text { The German } \\
\text { modified ICD system } \\
\text { was used to identify } \\
\text { admissions following } \\
\text { suicide attempts. }\end{array}$ & Low \\
\hline $\begin{array}{l}\text { 33. Chang, } \\
\text { KM. et } \\
\text { al. } \\
2020^{78}\end{array}$ & $\begin{array}{l}\text { Peer- } \\
\text { reviewed } \\
\text { article }\end{array}$ & $\begin{array}{l}\text { South Korea } \\
\text { (Chungnam } \\
\text { province) }\end{array}$ & $\begin{array}{l}\text { Single-centre study in a } \\
\text { trauma centre of one } \\
\text { hospital. Data appears to be } \\
\text { extracted from patients' } \\
\text { hospital electronic health } \\
\text { records. Episodes of self- } \\
\text { harm referred to the trauma } \\
\text { centre. Prevalence in March } \\
2020 \text { was compared to the } \\
\text { pooled estimates for years } \\
2015 \text { to } 2019 \text { and for March }\end{array}$ & $\begin{array}{l}\text { Episodes of } \\
\text { self-harm } \\
\text { referred to } \\
\text { the trauma } \\
\text { centre. }\end{array}$ & $\begin{array}{l}\text { The number of self- } \\
\text { harm episodes was } \\
\text { higher in March } 2020 \\
\text { compared to the } \\
\text { annual five-year } \\
\text { average, but not } \\
\text { compared to the } \\
2015-2019 \text { average } \\
\text { for March } \\
\text { specifically. }\end{array}$ & $\begin{array}{l}\text { The study only } \\
\text { included 'violent' } \\
\text { methods of self-harm } \\
\text { and was limited to } \\
\text { persons who } \\
\text { presented to hospital } \\
\text { and were treated by } \\
\text { the trauma centre. } \\
\text { The study was } \\
\text { underpowered, with }\end{array}$ & Low \\
\hline
\end{tabular}




\begin{tabular}{|c|c|c|c|c|c|c|c|}
\hline Authors & $\begin{array}{l}\text { Report } \\
\text { type }\end{array}$ & $\begin{array}{l}\text { Country } \\
\text { (region) of } \\
\text { study setting }\end{array}$ & $\begin{array}{l}\text { Study design and data } \\
\text { used }\end{array}$ & Outcome & Findings & $\begin{array}{l}\text { Comments/limitatio } \\
\text { ns including } \\
\text { considerations } \\
\text { from JBI checklist }\end{array}$ & $\begin{array}{l}\text { Quality } \\
\text { rating of } \\
\text { evidence } \\
\text { relating } \\
\text { specifically } \\
\text { to self- } \\
\text { harm }^{1}\end{array}$ \\
\hline & & & 2015 to 2019. & & $\begin{array}{l}\text { No change for ages } \\
10-19 \text { years. }\end{array}$ & $\begin{array}{l}9 \text { episodes of self- } \\
\text { harm observed } \\
\text { during March } 2020 .\end{array}$ & \\
\hline $\begin{array}{l}\text { 34. Chiba, } \\
\text { Lewis } \\
\text { et al. } \\
2021\end{array}$ & $\begin{array}{l}\text { Peer- } \\
\text { reviewed } \\
\text { article }\end{array}$ & USA (California) & $\begin{array}{l}\text { Examination of trauma } \\
\text { admissions from one } \\
\text { hospital. Clinical data were } \\
\text { extracted from routine } \\
\text { hospital records. The } \\
\text { lockdown period }\left(20^{\text {th }} \text { March }\right. \\
\left.\text { to } 30^{\text {th }} \text { June } 2020\right) \text { was } \\
\text { compared to the equivalent } \\
\text { calendar period in } 2019 . \\
\text { Numbers of a range of } \\
\text { trauma admissions, including } \\
\text { 'suicide-related trauma } \\
\text { admissions' examined. }\end{array}$ & $\begin{array}{l}\text { 'Suicide- } \\
\text { related } \\
\text { trauma } \\
\text { admissions' }\end{array}$ & $\begin{array}{l}\text { The number of } \\
\text { 'suicide-related } \\
\text { trauma admissions' } \\
\text { increased by } 38 \% \\
\text { from } 26 \text { in } 2019 \text { to } 36 \\
\text { in } 2020 \text {. This change } \\
\text { was not statistically } \\
\text { significant. }\end{array}$ & $\begin{array}{l}\text { The outcome only } \\
\text { included trauma- } \\
\text { related methods of } \\
\text { self-harm and } \\
\text { excluded other } \\
\text { methods, notably } \\
\text { self-poisoning, which } \\
\text { is the method used in } \\
\text { most hospital- } \\
\text { admitted self-harm } \\
\text { episodes. The exact } \\
\text { definition of the self- } \\
\text { harm outcome was } \\
\text { not reported. } \\
\text { The number of } \\
\text { 'suicide-related } \\
\text { trauma admissions' } \\
\text { was lower ( } 26 \text { in } \\
2019 \text { vs. } 36 \text { in } 2020) \text {. } \\
\text { The method of data } \\
\text { extraction from } \\
\text { clinical records was } \\
\text { not described. }\end{array}$ & Low \\
\hline $\begin{array}{l}\text { 35. Coates, } \\
\text { Marsha }\end{array}$ & Preprint & $\begin{array}{l}\text { USA (Portland, } \\
\text { Oregon) }\end{array}$ & $\begin{array}{l}\text { Data were extracted from } \\
\text { electronic health records at }\end{array}$ & $\begin{array}{l}\text { Hospital } \\
\text { presentations }\end{array}$ & $\begin{array}{l}\text { The number of } \\
\text { admissions for }\end{array}$ & $\begin{array}{l}\text { Methods of } \\
\text { extracting data from }\end{array}$ & Low \\
\hline
\end{tabular}




\begin{tabular}{|c|c|c|c|c|c|c|c|}
\hline Authors & $\begin{array}{l}\text { Report } \\
\text { type }\end{array}$ & $\begin{array}{l}\text { Country } \\
\text { (region) of } \\
\text { study setting }\end{array}$ & $\begin{array}{l}\text { Study design and data } \\
\text { used }\end{array}$ & Outcome & Findings & $\begin{array}{l}\text { Comments/limitatio } \\
\text { ns including } \\
\text { considerations } \\
\text { from JBI checklist }\end{array}$ & $\begin{array}{l}\text { Quality } \\
\text { rating of } \\
\text { evidence } \\
\text { relating } \\
\text { specifically } \\
\text { to self- } \\
\text { harm }^{1}\end{array}$ \\
\hline $\begin{array}{l}\text { Il et al. } \\
2021^{65}\end{array}$ & & & $\begin{array}{l}\text { one hospital. Monthly } \\
\text { numbers of hospital and ED } \\
\text { admissions for suicide } \\
\text { attempts among children and } \\
\text { adolescents (up to age 19) } \\
\text { were examined. }\end{array}$ & for self-harm & $\begin{array}{l}\text { suicide attempts was } \\
\text { not significantly } \\
\text { elevated during the } \\
\text { COVID-19 pandemic } \\
\text { (specific dates not } \\
\text { provided). }\end{array}$ & $\begin{array}{l}\text { electronic health } \\
\text { records were not } \\
\text { described. } \\
\text { Specific dates for } \\
\text { comparisons were } \\
\text { not clear. } \\
\text { No clear definition of } \\
\text { suicide attempt was } \\
\text { provided. }\end{array}$ & \\
\hline $\begin{array}{l}\text { 36. Gil- } \\
\text { Jardiné } \\
\text { ' Chenai } \\
\text { s et al. } \\
2021^{66}\end{array}$ & $\begin{array}{l}\text { Peer- } \\
\text { reviewed } \\
\text { article }\end{array}$ & $\begin{array}{l}\text { France } \\
\text { (Gironde) }\end{array}$ & $\begin{array}{l}\text { Free-text information held in } \\
\text { electronic health records at } \\
\text { an emergency medical } \\
\text { contact centre were } \\
\text { classified using a natural } \\
\text { language processing neural } \\
\text { network. Trends in reasons } \\
\text { for calls in } 2020 \text {, before, } \\
\text { during and after the } \\
\text { lockdown }\left(17^{\text {th }} \text { March to } 11^{\text {th }}\right. \\
\text { May } 2020) \text { were examined. }\end{array}$ & $\begin{array}{l}\text { Calls relating } \\
\text { to self-harm }\end{array}$ & $\begin{array}{l}\text { No discernible trends } \\
\text { were found in } \\
\text { frequency of calls } \\
\text { relating to self-harm. }\end{array}$ & $\begin{array}{l}\text { No definition of self- } \\
\text { harm was provided. } \\
\text { Statistical tests were } \\
\text { not reported. }\end{array}$ & Low \\
\hline $\begin{array}{l}\text { 37. Jacob } \\
\text { et al., } \\
202067\end{array}$ & $\begin{array}{l}\text { Peer- } \\
\text { reviewed } \\
\text { article }\end{array}$ & $\begin{array}{l}\text { Australia } \\
\text { (Westmead) }\end{array}$ & $\begin{array}{l}\text { Study of a single trauma } \\
\text { centre in Australian hospital } \\
\text { with data collected from a } \\
\text { prospective trauma registry. } \\
\text { Mean monthly number of } \\
\text { trauma admissions among } \\
\text { patients aged } 16 \text { years and } \\
\text { over during March and April }\end{array}$ & $\begin{array}{l}\text { Self-harm } \\
\text { admissions } \\
\text { to the trauma } \\
\text { unit. }\end{array}$ & $\begin{array}{l}\text { During March and } \\
\text { April } 2020, \text { no } \\
\text { difference in } \\
\text { admissions following } \\
\text { self-harm was seen } \\
\text { ( } 7 \text { in } 2020 \text { vs. an } \\
\text { average of } 3 \text { to } 6 \text { in } \\
2016 \text { to } 2019 \text { ). }\end{array}$ & $\begin{array}{l}\text { The methods of data } \\
\text { collection were not } \\
\text { described. } \\
\text { The study was } \\
\text { under-powered for } \\
\text { examination of mean } \\
\text { monthly self-harm }\end{array}$ & Low \\
\hline
\end{tabular}




\begin{tabular}{|c|c|c|c|c|c|c|c|}
\hline Authors & $\begin{array}{l}\text { Report } \\
\text { type }\end{array}$ & $\begin{array}{l}\text { Country } \\
\text { (region) of } \\
\text { study setting }\end{array}$ & $\begin{array}{l}\text { Study design and data } \\
\text { used }\end{array}$ & Outcome & Findings & $\begin{array}{l}\text { Comments/limitatio } \\
\text { ns including } \\
\text { considerations } \\
\text { from JBI checklist }\end{array}$ & $\begin{array}{l}\text { Quality } \\
\text { rating of } \\
\text { evidence } \\
\text { relating } \\
\text { specifically } \\
\text { to self- } \\
\text { harm }^{1}\end{array}$ \\
\hline & & & $\begin{array}{l}2020 \text { were compared to the } \\
\text { mean during the same } \\
\text { months in } 2016 \text { to } 2019 \text {. }\end{array}$ & & & $\begin{array}{l}\text { admissions. } \\
\text { Significance testing } \\
\text { was not presented } \\
\text { due to small } \\
\text { numbers. }\end{array}$ & \\
\hline $\begin{array}{l}\text { 38. Joyce, } \\
\text { Richard } \\
\text { son et } \\
\text { al. } \\
2021^{24}\end{array}$ & $\begin{array}{l}\text { Peer- } \\
\text { reviewed } \\
\text { article }\end{array}$ & $\begin{array}{l}\text { New Zealand } \\
\text { (Christchurch) }\end{array}$ & $\begin{array}{l}\text { Electronic health records at } \\
\text { the ED at Christchurch } \\
\text { Hospital. Two cohorts } \\
\text { consisted of 'pre-lockdown' } \\
\left(15^{\text {th }} \text { February to } 18^{\text {th }} \text { March }\right. \\
2020 \text { and 'lockdown' } \\
\left(26^{\text {th }} \text { March to } 28^{\text {th }} \text { April }\right. \\
2020) \text {. SNOMED codes were } \\
\text { extracted, followed by } \\
\text { detailed review of records by } \\
\text { the research team. }\end{array}$ & $\begin{array}{l}\text { Self-harm } \\
\text { presentations } \\
\text { to the ED }\end{array}$ & $\begin{array}{l}\text { Absolute numbers of } \\
\text { self-harm and } \\
\text { overdose } \\
\text { presentations before } \\
\text { lockdown were } \\
\text { reported as similar to } \\
\text { during lockdown: } \\
\text { self-harm: } 35 \text { before } \\
\text { lockdown vs. } 36 \\
\text { after; overdose: } 158 \\
\text { vs. } 128 . \\
\text { Though only reported } \\
\text { as a proportion of all } \\
\text { presentations, the } \\
\text { number of overdoses } \\
\text { involving } \\
\text { paracetamol with or } \\
\text { without ibuprofen } \\
\text { increased (22 pre- } \\
\text { lockdown vs. } 35 \\
\text { during lockdown). }\end{array}$ & $\begin{array}{l}\text { The study mainly } \\
\text { reports differences in } \\
\text { proportions of } \\
\text { presentations } \\
\text { involving self-harm } \\
\text { and overdose as a } \\
\text { proportion of overall } \\
\text { presentations. } \\
\text { Absolute differences } \\
\text { were reported in the } \\
\text { text. } \\
\text { The main } \\
\text { comparisons were } \\
\text { based on a pre- } \\
\text { lockdown period in } \\
2020 \text {, and therefore } \\
\text { seasonal variations } \\
\text { in presentation rates } \\
\text { were not accounted } \\
\text { for in the analyses. }\end{array}$ & Moderate \\
\hline $\begin{array}{l}\text { 39. Page, } \\
\text { Bandar }\end{array}$ & Letter & $\begin{array}{l}\text { Australia } \\
\text { (Sydney) }\end{array}$ & $\begin{array}{l}\text { Data were extracted from } \\
\text { one ED using hospital }\end{array}$ & $\begin{array}{l}\text { Number of } \\
\text { self-harm }\end{array}$ & $\begin{array}{l}\text { No significant } \\
\text { increase in }\end{array}$ & $\begin{array}{l}\text { Limited } \\
\text { methodological detail }\end{array}$ & Low \\
\hline
\end{tabular}




\begin{tabular}{|c|c|c|c|c|c|c|c|}
\hline Authors & $\begin{array}{l}\text { Report } \\
\text { type }\end{array}$ & $\begin{array}{l}\text { Country } \\
\text { (region) of } \\
\text { study setting }\end{array}$ & $\begin{array}{l}\text { Study design and data } \\
\text { used }\end{array}$ & Outcome & Findings & $\begin{array}{l}\text { Comments/limitatio } \\
\text { ns including } \\
\text { considerations } \\
\text { from JBI checklist }\end{array}$ & $\begin{array}{l}\text { Quality } \\
\text { rating of } \\
\text { evidence } \\
\text { relating } \\
\text { specifically } \\
\text { to self- } \\
\text { harm }^{1}\end{array}$ \\
\hline $\begin{array}{l}\text { a et al. } \\
202168\end{array}$ & & & $\begin{array}{l}\text { records. An established self- } \\
\text { harm field and text searches } \\
\text { were used to identify self- } \\
\text { harm. The period } 1^{\text {st }} \text { March } \\
\text { to } 31^{\text {st }} \text { July } 2020 \text { was } \\
\text { compared to the period } 1^{\text {st }} \\
\text { March } 2018 \text { to } 28^{\text {th }} \text { February } \\
\text { 2020). }\end{array}$ & $\begin{array}{l}\text { presentations } \\
\text { to the ED. }\end{array}$ & $\begin{array}{l}\text { intentional self-harm } \\
\text { in } \\
\text { the period from } \\
\text { March } 2020 \text { among } \\
\text { males or females. } \\
\text { An increase was } \\
\text { found for males from } \\
\text { the lowest } \\
\text { socioeconomic } \\
\text { position group. }\end{array}$ & $\begin{array}{l}\text { reported. Publication } \\
\text { is correspondence } \\
\text { rather than full } \\
\text { article. }\end{array}$ & \\
\hline $\begin{array}{l}\text { 40. Prados } \\
\text {-Ojeda, } \\
\text { Gordillo } \\
\text { - } \\
\text { Urbano } \\
\text { et al. } \\
2021) \\
69\end{array}$ & $\begin{array}{l}\text { Peer- } \\
\text { reviewed } \\
\text { article }\end{array}$ & Spain (Cordoba) & $\begin{array}{l}\text { The data were extracted from } \\
\text { an electronic health record } \\
\text { system. The lockdown } \\
\text { period, } 15^{\text {th }} \text { March to } 15^{\text {th }} \\
\text { May } \\
2020 \text { was compared with the } \\
\text { equivalent calendar period in } \\
2019 . \text { The main outcome } \\
\text { was 'suicide-related' ED } \\
\text { presentations which } \\
\text { coalesced 'suicide attempts' } \\
\text { and 'suicidal ideation'. The } \\
\text { number of suicide attempts } \\
\text { was, however, reported } \\
\text { separately for each } \\
\text { comparison period. }\end{array}$ & $\begin{array}{l}\text { ED } \\
\text { presentations } \\
\text { for suicide } \\
\text { attempt }\end{array}$ & $\begin{array}{l}\text { The number of } \\
\text { suicide attempts was } \\
\text { similar: } 86 \text { in the } \\
2019 \text { study period vs. } \\
73 \text { in the COVID-19 } \\
\text { period. } \\
\text { A higher proportion } \\
\text { of suicide attempts } \\
\text { required ICU } \\
\text { admission during the } \\
\text { COVID-19 period, } \\
\text { although event } \\
\text { counts were very } \\
\text { small. }\end{array}$ & $\begin{array}{l}\text { Self-harm } \\
\text { presentations not } \\
\text { recorded as 'suicide } \\
\text { attempt' were not } \\
\text { included. } \\
\text { No information on } \\
\text { methods used to } \\
\text { increase reliability of } \\
\text { data extraction was } \\
\text { provided. } \\
\text { Numbers of suicide } \\
\text { attempts were low. }\end{array}$ & Low \\
\hline $\begin{array}{l}\text { 41. Rajput } \\
\text { et al. } \\
2020\end{array}$ & $\begin{array}{l}\text { Peer- } \\
\text { reviewed } \\
\text { article }\end{array}$ & $\begin{array}{l}\text { England } \\
\text { (Merseyside) }\end{array}$ & $\begin{array}{l}\text { Data on trauma admissions } \\
\text { to a single level } 1 \text { trauma } \\
\text { centre in Liverpool were } \\
\text { collected from a trauma }\end{array}$ & $\begin{array}{l}\text { Numbers of } \\
\text { admissions } \\
\text { to trauma } \\
\text { centre }\end{array}$ & $\begin{array}{l}\text { No change in total } \\
\text { numbers of trauma } \\
\text { centre attendances } \\
\text { for self-harm in the }\end{array}$ & $\begin{array}{l}\text { Small sample size, } \\
\text { though } 95 \% \\
\text { confidence intervals } \\
\text { were presented. }\end{array}$ & Low \\
\hline
\end{tabular}




\begin{tabular}{|c|c|c|c|c|c|c|c|}
\hline Authors & $\begin{array}{l}\text { Report } \\
\text { type }\end{array}$ & $\begin{array}{l}\text { Country } \\
\text { (region) of } \\
\text { study setting }\end{array}$ & $\begin{array}{l}\text { Study design and data } \\
\text { used }\end{array}$ & Outcome & Findings & $\begin{array}{l}\text { Comments/limitatio } \\
\text { ns including } \\
\text { considerations } \\
\text { from JBI checklist }\end{array}$ & $\begin{array}{l}\text { Quality } \\
\text { rating of } \\
\text { evidence } \\
\text { relating } \\
\text { specifically } \\
\text { to self- } \\
\text { harm }^{1}\end{array}$ \\
\hline & & & $\begin{array}{l}\text { research network database. } \\
\text { Three 7-week periods were } \\
\text { compared: (1) Lockdown: } 23 \\
\text { March 2020-10 May 2020; } \\
\text { (2) Pre-lockdown: } 7 \text { weeks } \\
\text { prior to lockdown (27 } \\
\text { January 2020-15 March } \\
\text { 2020); (3) Pre-lockdown } \\
\text { 2019: equivalent 7-week } \\
\text { period in 2019 (25 March } \\
\text { 2019-12 May 2019). }\end{array}$ & $\begin{array}{l}\text { following } \\
\text { self-harm }\end{array}$ & $\begin{array}{l}\text { lockdown study } \\
\text { period }(n=14) \\
\text { compared to the } \\
\text { equivalent } 2019 \\
\text { period }(n=20) \text {. }\end{array}$ & $\begin{array}{l}\text { No definition of self- } \\
\text { harm was provided, } \\
\text { nor were details } \\
\text { about how data were } \\
\text { extracted. }\end{array}$ & \\
\hline $\begin{array}{l}\text { 42. (Shield } \\
\text { s, } \\
\text { Bernar } \\
\text { d et al. } \\
2021^{25}\end{array}$ & $\begin{array}{l}\text { Peer- } \\
\text { reviewed } \\
\text { article }\end{array}$ & $\begin{array}{l}\text { England } \\
\text { (Manchester) }\end{array}$ & $\begin{array}{l}\text { ED codes and electronic } \\
\text { health records were used to } \\
\text { collect data on admissions } \\
\text { from one adult ED. Numbers } \\
\text { of patients with a recorded } \\
\text { episode } \\
\text { of self-harm aged } 16 \text { years } \\
\text { and over were compared } \\
\text { between the COVID-19 } \\
\text { lockdown period ( } 1^{\text {st }} \text { March to } \\
\left.31^{\text {st }} \text { May } 2020\right) \text { and the } \\
\text { equivalent calendar periods } \\
\text { in } 2019 \text { and } 2020 \text {. }\end{array}$ & $\begin{array}{l}\text { Hospital } \\
\text { admission for } \\
\text { self-harm }\end{array}$ & $\begin{array}{l}\text { Admission } \\
\text { frequencies for self- } \\
\text { harm during the } 2020 \\
\text { COVID-19 period did } \\
\text { not differ significantly } \\
\text { from those for years } \\
2018 \text { and } 2019 \text {. }\end{array}$ & $\begin{array}{l}\text { Broad definition of } \\
\text { self-harm used. } \\
\text { ED presentations not } \\
\text { resulting in hospital } \\
\text { admission were not } \\
\text { included. } \\
\text { The outcome } \\
\text { measure relied on } \\
\text { accurate coding } \\
\text { within the ED. }\end{array}$ & Moderate \\
\hline $\begin{array}{l}\text { 43. Yeates, } \\
\text { Grigori } \\
\text { an et } \\
\text { al. } \\
2021^{71}\end{array}$ & $\begin{array}{l}\text { Peer- } \\
\text { reviewed } \\
\text { article }\end{array}$ & $\begin{array}{l}\text { USA (Southern } \\
\text { California) }\end{array}$ & $\begin{array}{l}\text { Multicentre study including } \\
11 \text { trauma centres. } \\
\text { Retrospective analysis of } \\
\text { registry data in each centre. } \\
\text { Suicide attempts were } \\
\text { included as a secondary }\end{array}$ & $\begin{array}{l}\text { Suicide } \\
\text { attempts } \\
\text { requiring } \\
\text { trauma } \\
\text { admission }\end{array}$ & $\begin{array}{l}\text { No statistically } \\
\text { significant change in } \\
\text { frequency of suicide } \\
\text { attempts leading to } \\
\text { treatment in trauma } \\
\text { centres. }\end{array}$ & $\begin{array}{l}\text { The study only } \\
\text { examined suicide } \\
\text { attempts leading to } \\
\text { treatment in a trauma } \\
\text { centre, which would } \\
\text { be a minority of all }\end{array}$ & Low \\
\hline
\end{tabular}




\begin{tabular}{|c|c|c|c|c|c|c|c|}
\hline Authors & $\begin{array}{l}\text { Report } \\
\text { type }\end{array}$ & $\begin{array}{l}\text { Country } \\
\text { (region) of } \\
\text { study setting }\end{array}$ & $\begin{array}{l}\text { Study design and data } \\
\text { used }\end{array}$ & Outcome & Findings & $\begin{array}{l}\text { Comments/limitatio } \\
\text { ns including } \\
\text { considerations } \\
\text { from JBI checklist }\end{array}$ & $\begin{array}{l}\text { Quality } \\
\text { rating of } \\
\text { evidence } \\
\text { relating } \\
\text { specifically } \\
\text { to self- } \\
\text { harm }^{1}\end{array}$ \\
\hline & & & $\begin{array}{l}\text { outcome in the study. A } \\
\text { COVID-19 period ( } 19^{\text {th }} \text { March } \\
\left.\text { to } 30^{\text {th }} \text { June } 2020\right) \text { was } \\
\text { compared to both a 'pre- } \\
\text { COVID-19' period ( } 1^{\text {st }} \\
\text { January } 2020 \text { to } 18^{\text {th }} \text { March } \\
2020) \text { and an antecedent } \\
\text { period }\left(19^{\text {th }} \text { March to June }\right. \\
\left.30^{\text {th }} 2019\right) \text {. }\end{array}$ & & & $\begin{array}{l}\text { suicide attempts } \\
\text { presenting to general } \\
\text { hospital EDs. Details } \\
\text { about the specific } \\
\text { methods used in the } \\
\text { suicide attempts } \\
\text { examined were not } \\
\text { provided. }\end{array}$ & \\
\hline $\begin{array}{l}\text { 44. Ougrin, } \\
\text { Wong } \\
\text { et al. } \\
2021^{27}\end{array}$ & $\begin{array}{l}\text { Peer- } \\
\text { reviewed } \\
\text { article }\end{array}$ & $\begin{array}{l}10 \text { high/middle } \\
\text { income } \\
\text { countries: } \\
\text { England, } \\
\text { Scotland, } \\
\text { Ireland, Austria, } \\
\text { Italy, Hungary, } \\
\text { Serbia, Turkey, } \\
\text { Oman, and the } \\
\text { United } \\
\text { Arab Emirates }\end{array}$ & $\begin{array}{l}\text { Electronic health records of } \\
23 \text { hospital EDs in } 10 \text { the } \\
\text { study countries. Hospital } \\
\text { presentations for self-harm } \\
\text { among children and } \\
\text { adolescents aged up to } 18 \\
\text { years were compared } \\
\text { between the period } 1^{\text {st }} \text { March } \\
\text { to } 30^{\text {th }} \text { April } 2020 \text { to the same } \\
\text { period in } 2019 \text {. Two self- } \\
\text { harm outcomes were } \\
\text { measured: a broad definition } \\
\text { based on the UK NICE } \\
\text { clinical guidelines and severe } \\
\text { self-harm, defined as } \\
\text { meeting criteria for high } \\
\text { lethality. However, } \\
\text { differences in incidence were } \\
\text { only reported for the broad } \\
\text { definition of self-harm. }\end{array}$ & $\begin{array}{l}\text { Hospital } \\
\text { presentation } \\
\text { for self-harm }\end{array}$ & $\begin{array}{l}\text { All study centres } \\
\text { reported significantly } \\
\text { fewer children and } \\
\text { adolescents with } \\
\text { self-harm } \\
\text { presentations during } \\
\text { the COVID-19 } \\
\text { observation period. } \\
\text { Monthly incidence of } \\
\text { children and } \\
\text { adolescents } \\
\text { presenting with self- } \\
\text { harm to EDs } \\
\text { (aggregated across } \\
\text { centres) during the } \\
\text { covid-19 pandemic } \\
\text { (2020: } n=470 \text { ) was } \\
\text { lower than in 2019 ( } \mathrm{n} \\
=612 \text { ). }\end{array}$ & $\begin{array}{l}\text { Interrater agreement } \\
\text { was assessed in the } \\
\text { coding of severe self- } \\
\text { harm presentations. } \\
\text { Much of the reporting } \\
\text { is focussed on } \\
\text { differences in the } \\
\text { proportions of total } \\
\text { psychiatric } \\
\text { emergencies due to } \\
\text { self-harm between } \\
\text { the two time periods, } \\
\text { rather than } \\
\text { differences in } \\
\text { presentation } \\
\text { frequencies. }\end{array}$ & Moderate \\
\hline $\begin{array}{l}\text { 45. Eray } \\
\text { and }\end{array}$ & $\begin{array}{l}\text { Peer- } \\
\text { reviewed }\end{array}$ & Turkey (Bursa) & $\begin{array}{l}\text { Data were from one } \\
\text { paediatric emergency service }\end{array}$ & $\begin{array}{l}\text { Numbers of } \\
\text { children and }\end{array}$ & $\begin{array}{l}\text { There were } 21 \\
\text { admissions in } 2019\end{array}$ & $\begin{array}{l}\text { Details of data } \\
\text { extraction were not }\end{array}$ & Low \\
\hline
\end{tabular}




\begin{tabular}{|c|c|c|c|c|c|c|c|}
\hline Authors & $\begin{array}{l}\text { Report } \\
\text { type }\end{array}$ & $\begin{array}{l}\text { Country } \\
\text { (region) of } \\
\text { study setting }\end{array}$ & $\begin{array}{l}\text { Study design and data } \\
\text { used }\end{array}$ & Outcome & Findings & $\begin{array}{l}\text { Comments/limitatio } \\
\text { ns including } \\
\text { considerations } \\
\text { from JBI checklist }\end{array}$ & $\begin{array}{l}\text { Quality } \\
\text { rating of } \\
\text { evidence } \\
\text { relating } \\
\text { specifically } \\
\text { to self- } \\
\text { harm }^{1}\end{array}$ \\
\hline $\begin{array}{l}\text { Sahin } \\
2021\end{array}$ & article & & $\begin{array}{l}\text { during the COVID-19 period } \\
\left(11^{\text {th }} \text { March to }\right. \\
30^{\text {th }} \text { September } 2020 \text { were } \\
\text { compared to those admitted } \\
\text { during the equivalent } \\
\text { calendar period in } 2019 .\end{array}$ & $\begin{array}{l}\text { adolescents } \\
\text { admitted } \\
\text { following a } \\
\text { suicide } \\
\text { attempt. }\end{array}$ & $\begin{array}{l}\text { vs. } 9 \text { in 2020, a 57\% } \\
\text { reduction. }\end{array}$ & $\begin{array}{l}\text { provided. } \\
\text { Suicide attempt was } \\
\text { not defined. } \\
\text { Low event counts. } \\
\text { No statistical test for } \\
\text { the absolute } \\
\text { difference was } \\
\text { reported. }\end{array}$ & \\
\hline $\begin{array}{l}\text { 46. Fidancı } \\
\text {, Taşar } \\
\text { et al. } \\
2021{ }^{73}\end{array}$ & $\begin{array}{l}\text { Peer- } \\
\text { reviewed } \\
\text { article. }\end{array}$ & Turkey (Ankara) & $\begin{array}{l}\text { Data were extracted from } \\
\text { electronic health records } \\
\text { from one paediatric ED. } \\
\text { Numbers of consultations for } \\
\text { patients aged } 18 \text { years and } \\
\text { under during } 1^{\text {st }} \text { April to } 31^{\text {st }} \\
\text { October } 2020 \text { were } \\
\text { compared to the equivalent } \\
\text { calendar period in } 2019 \text {. }\end{array}$ & $\begin{array}{l}\text { ED visits for } \\
\text { suicide } \\
\text { attempts. }\end{array}$ & $\begin{array}{l}\text { During the } \\
\text { antecedent April to } \\
\text { October } 2019 \text { period } \\
\text { there were } 187 \text { visits } \\
\text { for suicide attempts } \\
\text { vs. } 31 \text { for the } \\
\text { equivalent COVID-19 } \\
\text { period in } 2020 \text {. }\end{array}$ & $\begin{array}{l}\text { No information on } \\
\text { the definition of } \\
\text { suicide attempt } \\
\text { applied was given. } \\
\text { No statistical test for } \\
\text { the absolute } \\
\text { difference was } \\
\text { reported. }\end{array}$ & Low \\
\hline $\begin{array}{l}\text { 47. Thongc } \\
\text { huam, } \\
\text { Mahaw } \\
\text { ongkajit } \\
\text { et al. } \\
2021^{23}\end{array}$ & $\begin{array}{l}\text { Peer- } \\
\text { reviewed } \\
\text { article }\end{array}$ & $\begin{array}{l}\text { Thailand } \\
\text { (Northern } \\
\text { Bangkok) }\end{array}$ & $\begin{array}{l}\text { Data were extracted from } \\
\text { electronic health records of } \\
\text { one university teaching } \\
\text { hospital } \\
\text { between June and December } \\
2019 \text { (pre-COVID-19) and } \\
\text { January to June } 2020 \\
\text { (COVID- } \\
19 \text { period). Numbers of adult } \\
\text { patients aged } 18 \text { years and }\end{array}$ & $\begin{array}{l}\text { Self- } \\
\text { poisoning } \\
\text { with } \\
\text { corrosive } \\
\text { substances }\end{array}$ & $\begin{array}{l}\text { More patients were } \\
\text { admitted during the } \\
\text { COVID-19 period: } 20 \\
\text { vs. } 9 \text { in the pre- } \\
\text { COVID-19 period. }\end{array}$ & $\begin{array}{l}\text { Analysis did not } \\
\text { account for seasonal } \\
\text { variation. } \\
\text { Low event counts. } \\
\text { Focussed only on } \\
\text { self-harm involving } \\
\text { corrosive substances } \\
\text { requiring surgery, }\end{array}$ & Moderate \\
\hline
\end{tabular}




\begin{tabular}{|c|c|c|c|c|c|c|c|}
\hline Authors & $\begin{array}{l}\text { Report } \\
\text { type }\end{array}$ & $\begin{array}{l}\text { Country } \\
\text { (region) of } \\
\text { study setting }\end{array}$ & $\begin{array}{l}\text { Study design and data } \\
\text { used }\end{array}$ & Outcome & Findings & $\begin{array}{l}\text { Comments/limitatio } \\
\text { ns including } \\
\text { considerations } \\
\text { from JBI checklist }\end{array}$ & $\begin{array}{l}\text { Quality } \\
\text { rating of } \\
\text { evidence } \\
\text { relating } \\
\text { specifically } \\
\text { to self- } \\
\text { harm }^{1}\end{array}$ \\
\hline & & & $\begin{array}{l}\text { over who had ingested a } \\
\text { corrosive substance and } \\
\text { been admitted to surgical } \\
\text { department were compared } \\
\text { between the two time } \\
\text { periods. }\end{array}$ & & & $\begin{array}{l}\text { though this is a } \\
\text { common method of } \\
\text { self-harm in Asian } \\
\text { countries. }\end{array}$ & \\
\hline $\begin{array}{l}\text { 48. Staševi } \\
\text { ć- } \\
\text { Karličić } \\
\text { Đorđevi } \\
\text { ć et al. } \\
2021^{74}\end{array}$ & $\begin{array}{l}\text { Peer- } \\
\text { reviewed } \\
\text { article }\end{array}$ & $\begin{array}{l}\text { Serbia } \\
\text { (Belgrade) }\end{array}$ & $\begin{array}{l}\text { Data were extracted from } \\
\text { electronic health records at a } \\
\text { psychiatric ED. The study } \\
\text { compared two periods: the } \\
\text { period from March to August } \\
2020 \text { (the COVID-19 period) } \\
\text { and the same period in } 2019 \text {. }\end{array}$ & $\begin{array}{l}\text { Number of } \\
\text { patients } \\
\text { examined at } \\
\text { a psychiatric } \\
\text { ED due to } \\
\text { suicide } \\
\text { attempts. }\end{array}$ & $\begin{array}{l}\text { A statistically } \\
\text { significant increase } \\
\text { in the number of } \\
\text { suicide attempts } \\
\text { during the COVID-19 } \\
\text { period was observed } \\
\text { (159 persons during } \\
\text { COVID period and } \\
139 \text { persons during } \\
\text { the } \\
\text { non-COVID period). }\end{array}$ & $\begin{array}{l}\text { The definition of } \\
\text { 'suicide attempt' was } \\
\text { not provided, though } \\
\text { the authors stated it } \\
\text { included self- } \\
\text { poisoning, } \\
\text { self-injury, jumping } \\
\text { from height and self- } \\
\text { ignition. Methods of } \\
\text { identifying patients } \\
\text { meeting the inclusion } \\
\text { criteria were not } \\
\text { described and data } \\
\text { collection methods } \\
\text { were not provided. }\end{array}$ & Low \\
\hline $\begin{array}{l}\text { 49. Knipe, } \\
\text { Silva et } \\
\text { al. } \\
2021^{20}\end{array}$ & $\begin{array}{l}\text { Peer- } \\
\text { reviewed } \\
\text { article }\end{array}$ & $\begin{array}{l}\text { Sri Lanka } \\
\text { (Kandy) }\end{array}$ & $\begin{array}{l}\text { Electronic health record data } \\
\text { from a toxicology unit at one } \\
\text { hospital were used to identify } \\
\text { presentations of self- } \\
\text { poisoning. Additional data } \\
\text { was then collected from } \\
\text { routinely collected clinical } \\
\text { records. Numbers of self- } \\
\text { poisoning presentations to } \\
\text { hospital were compared }\end{array}$ & $\begin{array}{l}\text { Self- } \\
\text { poisoning } \\
\text { presentations } \\
\text { to hospital }\end{array}$ & $\begin{array}{l}\text { There was a } 32 \% \\
\text { reduction in hospital } \\
\text { presentations for } \\
\text { self-poisoning in the } \\
\text { pandemic period } \\
\text { compared with pre- } \\
\text { pandemic trends. }\end{array}$ & $\begin{array}{l}\text { Pre-pandemic trends } \\
\text { were accounted for. } \\
\text { Proportions of } \\
\text { missing data in the } \\
\text { pre-pandemic and } \\
\text { pandemic periods } \\
\text { were compared. }\end{array}$ & $\begin{array}{l}\text { High/moder } \\
\text { ate }\end{array}$ \\
\hline
\end{tabular}




\begin{tabular}{|c|c|c|c|c|c|c|c|}
\hline Authors & $\begin{array}{l}\text { Report } \\
\text { type }\end{array}$ & $\begin{array}{l}\text { Country } \\
\text { (region) of } \\
\text { study setting }\end{array}$ & $\begin{array}{l}\text { Study design and data } \\
\text { used }\end{array}$ & Outcome & Findings & $\begin{array}{l}\text { Comments/limitatio } \\
\text { ns including } \\
\text { considerations } \\
\text { from JBI checklist }\end{array}$ & $\begin{array}{l}\text { Quality } \\
\text { rating of } \\
\text { evidence } \\
\text { relating } \\
\text { specifically } \\
\text { to self- } \\
\text { harm }^{1}\end{array}$ \\
\hline & & & $\begin{array}{l}\text { between a pre-pandemic } \\
\text { period ( } 1^{\text {st }} \text { January } 2019 \text { to } \\
\left.19^{\text {th }} \text { March } 2020\right) \text { and the } \\
\text { pandemic period }\left(20^{\text {th }} \text { March }\right. \\
\left.\text { to } 31^{\text {st }} \text { August } 2020\right) \text {. }\end{array}$ & & & & \\
\hline $\begin{array}{l}\text { 50. Jhanwa } \\
\text { r et al., } \\
2020\end{array}$ & $\begin{array}{l}\text { Peer- } \\
\text { reviewed } \\
\text { article }\end{array}$ & $\begin{array}{l}\text { India } \\
\text { (Rishikesh) }\end{array}$ & $\begin{array}{l}\text { Before and after cross- } \\
\text { sectional prevalence study. } \\
\text { Liaison psychiatry case } \\
\text { records of all patients } \\
\text { admitted to the emergency } \\
\text { department (ED) of a } \\
\text { government tertiary care } \\
\text { teaching hospital comparing } \\
\text { before lockdown (February } \\
24 \text { to March } 23,2020 \text { ) to } \\
\text { lockdown: March } 24 \text { to April } \\
23,2020 \text { ). }\end{array}$ & $\begin{array}{l}\text { Suicide } \\
\text { attempt/self- } \\
\text { harm } \\
\text { identified } \\
\text { from } \\
\text { electronic } \\
\text { health } \\
\text { records. }\end{array}$ & $\begin{array}{l}\text { Reduced total } \\
\text { attendances: } 51 \\
\text { before lockdown vs. } \\
32 \text { during lockdown. }\end{array}$ & $\begin{array}{l}\text { The study included } \\
\text { only a short } \\
\text { timeframe and the } \\
\text { numbers of patients } \\
\text { included was } \\
\text { relatively small. } \\
\text { The definitions of } \\
\text { 'self-harm and } \\
\text { 'suicide attempt' } \\
\text { applied are unclear. } \\
\text { Methods of data } \\
\text { extraction, for } \\
\text { example, the } \\
\text { between-rater } \\
\text { reliability of } \\
\text { identifying 'suicide } \\
\text { attempt' was not } \\
\text { discussed. }\end{array}$ & Low \\
\hline $\begin{array}{l}\text { 51. Shresth } \\
\text { a, } \\
\text { Siwako } \\
\text { ti et al. } \\
2021^{26}\end{array}$ & $\begin{array}{l}\text { Peer- } \\
\text { reviewed } \\
\text { article }\end{array}$ & $\begin{array}{l}\text { Nepal } \\
\text { (Dhulikhel) }\end{array}$ & $\begin{array}{l}\text { One ED in a university } \\
\text { teaching hospital. Electronic } \\
\text { health records were used to } \\
\text { conduct this study of } \\
\text { presentations involving fatal } \\
\text { and non-fatal episodes of }\end{array}$ & $\begin{array}{l}\text { Frequency of } \\
\text { self-harm } \\
\text { presentations } \\
\text {, referral } \\
\text { status and in- } \\
\text { hospital and }\end{array}$ & $\begin{array}{l}\text { The number of self- } \\
\text { harm presentations } \\
\text { in the lockdown } \\
\text { period increased by } \\
44 \% \text { compared to the } \\
\text { equivalent period in }\end{array}$ & $\begin{array}{l}\text { The keywords used } \\
\text { to search the } \\
\text { electronic health } \\
\text { records were } \\
\text { provided and } \\
\text { included a broad }\end{array}$ & Moderate \\
\hline
\end{tabular}




\begin{tabular}{|c|c|c|c|c|c|c|c|}
\hline Authors & $\begin{array}{l}\text { Report } \\
\text { type }\end{array}$ & $\begin{array}{l}\text { Country } \\
\text { (region) of } \\
\text { study setting }\end{array}$ & $\begin{array}{l}\text { Study design and data } \\
\text { used }\end{array}$ & Outcome & Findings & $\begin{array}{l}\text { Comments/limitatio } \\
\text { ns including } \\
\text { considerations } \\
\text { from JBI checklist }\end{array}$ & $\begin{array}{l}\text { Quality } \\
\text { rating of } \\
\text { evidence } \\
\text { relating } \\
\text { specifically } \\
\text { to self- } \\
\text { harm }^{1}\end{array}$ \\
\hline & & & $\begin{array}{l}\text { self-harm. The lockdown } \\
\text { period }\left(24^{\text {th }} \text { March to } 23^{\text {rd }}\right. \\
\text { June } 2020) \text { was compared to } \\
\text { the equivalent calendar } \\
\text { period in } 2019 \text { and the period } \\
\text { prior to the lockdown }\left(24^{\text {th }}\right. \\
\text { December } 2019 \text { to } 23^{\text {rd }} \\
\text { March 2020). }\end{array}$ & $\begin{array}{l}\text { overall } \\
\text { mortality. }\end{array}$ & 2019. & $\begin{array}{l}\text { definition of self- } \\
\text { harm. } \\
\text { The numbers of } \\
\text { presentations in were } \\
\text { relatively small ( } 55 \text { in } \\
\text { the lockdown period } \\
\text { and } 38 \text { in the } 2019 \\
\text { comparison period) } \\
\text { and the comparison } \\
\text { periods were also } \\
\text { brief. }\end{array}$ & \\
\hline
\end{tabular}

${ }^{1}$ high/moderate quality if risk of bias is considered low (i.e. Q3, Q6, Q7 \& Q8 on adapted JBI for before/after studies all scored "yes".) 


\section{Supplement 2: Search strategies for "The impact of the COVID-19 pandemic on self-harm and suicidal behaviour: update of living systematic review" and associated publications}

Scopus

TITLE-ABS-KEY("selfharm*" OR "self harm*" OR "self-harm*" OR "self injur*" OR "selfinjur*" OR "self-injur*" OR "selfmutilat*" OR "self mutilat*" OR "self-mutilat*" OR "suicid*" OR "parasuicid*" OR "suicide" OR "suicidal ideation" OR "attempt* suicide" OR "suicide attempt*" OR "drug overdose" OR "selfpoisoning" OR "self poisoning" OR "self-poisoning" OR "selfinjurious behavi*" OR "selfmutilation" OR "self mutilation" OR "self-mutilation" OR "automutilation" OR "suicidal behavi*" OR "selfdestructive behavi*" OR "self destructive behavi*" OR "self-destructive behavi*" OR "selfimmolat*" OR "self-immolat*" OR "self immolat*" OR "cutt*" OR "headbang" OR "head-bang" OR "head bang" OR "overdose" OR "selfinflict*" OR "self-inflict*" OR "self inflict*" OR "hopelessness" OR "powerlessness" OR "helplessness" OR "negative attitude*" OR "emotional negativism" OR "pessimism" OR "depress*" OR "hopelessness depression" OR "passivity" OR "sad-affect" OR "sadness" OR "decreased affect" OR "cognitive rigidity" OR "suicidality" OR "suicide ideation") AND TITLE-ABSKEY("nCoV" OR "HCoV" OR "covid 19" OR "covid-19" OR "covid19" OR "coronavirus" OR "19 ncov" OR "19-ncov" OR "2019 ncov" OR "2019-ncov" OR "2019ncov" OR "n-cov" OR "ncov" OR "coronavirus disease*" OR "sars-cov-2" OR "sars cov 2" OR "sars-cov 2" OR "mers-cov" OR "mers cov") AND PUBYEAR > 2020

?. The filter 'PUBYEAR $>2020$ ' corresponds to the 2021 version of this search, in previous years we used 'PUBYEAR $>2018$ ' and 'PUBYEAR $>2019$ ' respectively

Medline via PubMed

( (mental health[TIAB] OR selfharm*[TIAB] OR self-harm*[TIAB] OR selfinjur*[TIAB] OR self-

injur*[TIAB] OR selfmutilat*[TIAB] OR self-mutilat*[TIAB] OR suicid*[TIAB] OR parasuicid*[TIAB) $O R$ (suicide[TIAB] OR suicidal ideation[TIAB] OR attempted suicide[TIAB]) OR (drug overdose[TIAB] OR self?poisoning[TIAB]) OR (self-injurious behavio?r[TIAB] OR self?mutilation [TIAB] OR automutilation [TIAB] OR suicidal behavio?r[TIAB] OR self?destructive behavio?r[TIAB] OR self?immolation[TIAB])) OR (cutt*[TIAB] OR head?bang[TIAB] OR overdose[TIAB] OR self?immolat*[TIAB] OR self?inflict*[TIAB]) OR (hopelessness[TIAB] OR powerlessness[TIAB] OR helplessness[TIAB] OR negative attitude $\$$ [TIAB] OR emotional negativism[TIAB] OR pessimism [TIAB] OR depress*[TIAB] OR hopelessness depression[TIAB] OR passivity [TIAB] OR sad-affect[TIAB] OR sadness[TIAB] OR decreased affect[TIAB] OR cognitive rigidity $[T I A B]$ OR suicidality[TIAB] OR suicide ideation [TIAB]))) AND ((coronavirus disease?19[TIAB] OR sars?cov?2[TIAB] OR mers?cov[TIAB]) OR (19?ncov[TIAB] OR 2019 ? $n \operatorname{cov}[T I A B]$ OR $n$ ? $\operatorname{cov}[T I A B]$ ) OR (\"severe acute respiratory syndrome coronavirus $2 \backslash "$ [Supplementary Concept] OR \"COVID-19\" [Supplementary Concept] OR COVID-19 [tw] OR COVID 2019 [tw] OR coronavirus [tw] OR nCoV[TIAB] OR HCoV)) 
Psy- and SocArXiv (both same query)

"(mental health OR selfharm* OR self-harm* OR selfinjur* OR self-injur* OR selfmutilat* OR self-mutilat* OR suicid* OR parasuicid* OR suicide OR suicidal ideation OR attempted suicide OR drug overdose OR self?poisoning OR self-injurious behavio?r OR self?mutilation OR automutilation OR suicidal behavio?r OR self?destructive behavio?r OR self?immolation OR cutt* OR head?bang OR overdose OR self?immolat* OR self?inflict* OR hopelessness OR powerlessness OR helplessness OR negative attitude OR emotional negativism OR pessimism OR depress* OR hopelessness depression OR passivity OR sad-affect OR sadness OR decreased affect OR cognitive rigidity OR suicidality OR suicide ideation) AND (coronavirus disease?19 OR sars?cov?2 OR mers?cov OR 19?ncov OR 2019?ncov OR n?cov OR COVID-19 OR COVID 2019 OR coronavirus OR nCoV OR HCOV)"

\section{? No date/content filters applied}

Med and BioRxiv, WHO Covid-19 database

We directly retrieve ALL new publications related to Covid-19 from these sources, see http://connect.biorxiv.org/relate/content/181 for Bio-MedRxiv Covid feed and https://search.bvsalud.org/global-literature-on-novel-coronavirus-2019-ncov/for WHO on a daily basis. There is no date filter, we retrieve each new report as it becomes available. We then apply our systematic search to those results, as described here: McGuinness et al., (2020). medrxivr: Accessing and searching medRxiv and bioRxiv preprint data in R. Journal of Open Source Software, 5(54), 2651. https://doi.org/10.21105/joss.02651 The search strategy is below, please note that the syntax is RegularExpression, but it was designed to correspond to the PubMed query you see above, with new lines being joined with 'OR' statements. The only exception is the removal of the AND statement relating to COVID-19 itself, because those 3 sources only include COVID-specific information.

[Ss]elf[- ]?[li]njur(y|ious)[- ]?[Bb]ehaviou?r

[Ss]elf[- ]?([Mm]utilat-[li]mmolat)(ion | ed)

[Aa]uto[- ]?[Mm]utilat(ion | ed)

[Ss]uicidal[- ]?[Bb]ehaviou?r

[Ss]elf[- ]?[Dd]estructive)[- ]?[Bb] ehaviou?r

[Ss]uicide

[Aa]ttempted[- ]?[Ss]uicide

[Ss]uicidal[- ]?[li]deation

[Ss]elf[- ]?[Hh]arm

[Ss]elf[- ]?[Mm]utilat

[Ss]elf[- ]?[li]njur

[Pp]ara[ -]?[Ss]uicid

[Dd]rug[-]?[Oo]verdose

[Ss]elf[- ]?[Pp]oison(ing $\mid$ ed) 
[Ss]elf[- ]?[il]nflict

[Ss]elf[- ]?[il]mmolat

[CC]utt

[Hh]ead[- ]?[Bb]ang

[Oo]verdos

[Hh]opelessness

[Pp]owerlessness

[Hh]elplessness

[Nn]egative[-]?[Aa]ttitude

[Ee]motional[- ]?[Nn]egativism

[Pp]essimism

[Dd]epress

[Pp]assivity

[Ss]ad[- ]?[Aa]ffect

[Ss]adness

[Dd]ecreased[- ]?[Aa]ffect

[Cc]ognitive[- ]?[Rr]igidity

[Ss]uicidality

[Ss]uicide[- ]?[li]deation

[Mm]ental[ - ]?[Hh]ealth

[Mm]ental[ - ]?[Hh]ealth [-]?([CC]ris[ei]s| emergenc)

([pP]sychiatric|[Pp]sychotic|[Ss]chizophren $\left|w^{*}\right|[\mathrm{Bb}]$ ipolar $\mid[\mathrm{Mm}]$ ental $\mid \mathrm{w}^{*}\left([\mathrm{li}] \||| \mathrm{w}^{*} \mid[\mathrm{Dd}]\right.$ isorder $\left.)\right)[-$ ]?([Cc]ris[ie]s|[Ee]mergenc|[Aa]cute)

([Cc]ris[ie]s|[Ee]mergenclw*|[Aa]cute)[-

]?([pP]sychiatric|[Pp]sychotic|[Ss]chizophren $\left|\mathrm{w}^{*}\right|[\mathrm{Bb}] \mathrm{ipolar} \mid[\mathrm{Mm}]$ ental| $\mathrm{w}^{*}\left([\mathrm{li}] \| \mathrm{w}^{*} \mid[\mathrm{Dd}]\right.$ isorder $\left.)\right)$ 